\title{
Universiteit
}

Leiden

The Netherlands

\section{Provenance, Profile and Purpose of the Greek Joshua}

Meer, M.N. van der; Peters M.K.H.

\section{Citation}

Meer, M. N. van der. (2006). Provenance, Profile and Purpose of the Greek Joshua. Xii Congress Of The International Organization For Septuagint And Cognate Studies, Leiden 2004, 55-80. Retrieved from https://hdl.handle.net/1887/14075

Version: $\quad$ Not Applicable (or Unknown)

License: $\quad$ Leiden University Non-exclusive license

Downloaded from: https://hdl.handle.net/1887/14075

Note: To cite this publication please use the final published version (if applicable). 


\title{
Provenance, Profile, and Purpose OF THE GREeK JOSHUA*
}

\author{
Michaël N. van der Meer
}

\begin{abstract}
It is generally believed that the Greek translation of Joshua originated in approximately the same period and place as the Greek Pentateuch, but evidence to substantiate such a third-century B.C.E. Egyptian provenance of the Greek Joshua is hard to find. The present contribution examines possible reflections of the Greek Joshua in Jewish Greek literature of the pre-Christian era (particularly Aristobulus). It is further argued that a third-century B.C.E. origin of the Greek Joshua may account for some unusual Greek renderings of toponyms. On the basis of the lexical choices and literary initiatives, the profile of the Greek translator is sketched, a profile that seems to fit to some extent Drimylos and his son Dositheos, known from documentary papyri. Finally, it is argued that the Greek Joshua serves cultural propaganda and contemporary politics rather than religious needs.
\end{abstract}

\section{INTRODUCTION}

When was the Greek translation of Joshua made and where? Who made it, and for whom was it made? Who wanted a Greek translation of precisely this book? These questions are readily raised but difficult to answer. We have no information comparable to the Letter of Aristeas or the colophons on the Greek Esther or the Wisdom of Ben Sira that provides details on the origin of the Greek Joshua. Whereas the Greek Pentateuch, the Minor Prophets, and the Letter of Jeremiah are attested by papyri from the pre-Christian period, ${ }^{1}$ there are no manuscripts of the Greek version of Joshua or its daughter versions prior to the second century C.E. ${ }^{2}$

${ }^{\star}$ I wish to express my gratitude to L. Greenspoon, J. Joosten, A. van der Kooij, Th. van der Louw, and $\mathrm{E}$. Tov for their valuable comments on previous drafts of this paper.

1. Gilles Dorival, Marguerite Harl, and Olivier Munnich, La Bible grecque des Septante: Du judaïsme hellénistique au christianisme ancien (2nd ed.; Paris: Cerf, 1994), 132-33.

2. The oldest witnesses to LXX-Joshua are (1) the recently discovered Papyrus Schøyen 2648 (Rahlfs number 816), dating from the late second century C.E., with the remains of LXXJosh 9:27-11:3; (2) the fourth-century C.E. Oxyrhynchus Papyrus no. 1168, with remains of LXX-Josh 4:23-5:1; (3) the fourth-century C.E. Codex Vaticanus; and (4) the fourth-century C.E. Sahidic Joshua-Tobit Codex, now divided over the Irish Chester Beatty (no. 1389) and the Swiss Bodmer (no. xxi) libraries; see Michaël N. van der Meer, Formation and Reformulation: The

$$
-55-
$$

This essay was published in XII Congress of the International Organization for Septuagint and Cognate Studies, edited by Melvin K. H. Peters, copyright @ 2006 by the Society of Biblical Literature. To purchase copies of this book, please contact SBL Customer Service by phone at 877-725-3334 [toll-free in North America] or 802-864-6185, by fax at 802-864-7626, or by visiting the online SBL Store at www.sbl-site.org. 
Yet most scholars assume that the Greek translation of Joshua "followed soon after the Greek translation of the Pentateuch," thus Henry St. John Thackeray, since the relatively free translation technique of the Greek Joshua resembles that of the Pentateuch. ${ }^{3}$ It clearly contrasts with the very literal translation technique found in the Greek Judges and other "Septuagintal" books, a thesis now substantiated by the dissertation of Seppo Sipilä. ${ }^{4}$ Already in 1909 Henry Redpath was able to group the Greek Joshua with the Greek Pentateuch on the basis of the various renderings of the divine name. ${ }^{5}$

Gilles Dorival in the recent French introduction to the Septuagint considers the date of the Greek translation of Ben Sira with its references to the Greek Joshua in Sir 46:1-6 as a terminus ante quem for the Greek Joshua. ${ }^{6}$ Dorival finds an Alexandrian origin of the Greek Joshua probable, given the fact that it does not display the characteristics of the Kaige recension, which had its origin in Palestine. ${ }^{7}$ Yet already in 1973 G. B. Caird made it clear that the portrait of Joshua in the Greek Ben Sira shows no influence of the Greek Joshua. ${ }^{8}$ Finding evidence for

Redaction of the Book of Joshua in the Light of the Oldest Textual Witnesses (VTSup 102; Leiden: Brill, 2004), 22ff.

3. Henry St. J. Thackeray, Introduction, Orthography and Accidence (vol. 1 of A Grammar of the Old Testament in Greek according to the Septuagint; Cambridge: Cambridge University Press, 1909), 13.

4. Seppo Sipilä, Between Literalness and Freedom: Translation Technique in the Septuagint of Joshua and Judges regarding the Clause Connections introduced by 1 and כי (Publications of the Finnish Exegetical Society 75; Helsinki: Finnish Exegetical Society; Göttingen: Vandenhoeck \& Ruprecht, 1999). For a survey of scholarly study on the Greek Joshua, see van der Meer, Formation and Reformulation, 21-91.

5. Henry A. Redpath, "A Contribution towards Settling Dates of the Translation of the Various Books of the Septuagint," JTS 6 (1907): 606-14. Another significant distinction between the Greek Pentateuch and the Greek Joshua, on the one hand, and the other Septuagintal books is offered by the Greek translators' handling of the Hebrew word for Philistines (פלשתים). The

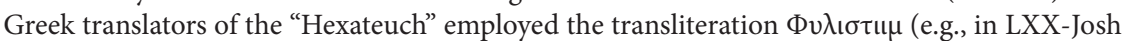
13:2, 3, 5), while all other Greek translators used the somewhat pejorative rendering à $\lambda \lambda$ ó $\varphi v \lambda o c ;$ see Roland de Vaux, "Les Philistins dans la Septante," in Wort, Lied und Gottesspruch: Beiträge zur Septuaginta (ed. J. Schreiner; Würzburg: Echter, 1972), 185-94.

6. Gilles Dorival, "Lachèvement de la Septante dans le judaïsme," in Dorival, Harl, and Munnich, La Bible grecque des Septante, 83-125, especially 96.

7. Ibid., 105.

8. George B. Caird, "Ben Sira and the Dating of the Septuagint," in Studia Evangelica 7: Papers Presented to the Fifth International Congress on Biblical Studies Held at Oxford, 1973 (ed. E. A. Livingstone; Berlin: Akademie 1982), 95-100. For example, whereas the Greek translator

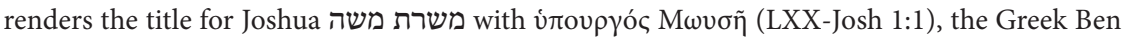

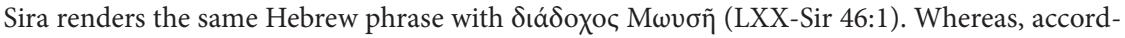

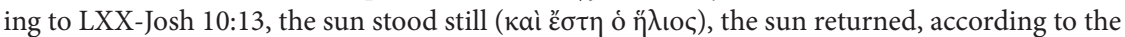

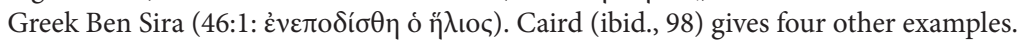

This essay was published in XII Congress of the International Organization for Septuagint and Cognate Studies, edited by Melvin K. H. Peters, copyright @ 2006 by the Society of Biblical Literature. To purchase copies of this book, please contact SBL Customer Service by phone at 877-725-3334 [toll-free in North America] or 802-864-6185, by fax at 802-864-7626, or by visiting the online SBL Store at www.sbl-site.org. 
a third-century B.C.E. Alexandrian provenance of the Greek Joshua thus remains very difficult.

To the best of my knowledge, only Kees den Hertog in his 1996 dissertation has made a comprehensive attempt to substantiate this hypothesis. ${ }^{9}$ Part of his argumentation is based upon a relative chronology between Deuteronomy, Joshua, and Judges. He concludes that the Greek Judges borrowed some translations from the Greek Joshua, which in turn itself shows the influence of the Greek Deuteronomy. ${ }^{10}$ Especially important for den Hertog's argumentation are the geographical data, which allow him to conclude that the Greek translation was made before the introduction of the Seleucid reorganization of Palestine around 198 B.C.E. ${ }^{11}$

Although I have some doubts with respect to several details, I basically agree with the scholars mentioned above. It is my intention to find further evidence for a third-century B.C.E. origin of the Greek Joshua by examining the external evidence posed by Greek Jewish writings of the pre-Christian period and the internal evidence found in the Greek translation itself, with special emphasis on the Greek translator's handling of geographical information and his own interests and competences, as evidenced by his lexical choices and literary initiatives. At the end of this paper a proposal is made for the producers, purposes, and public behind the Greek Joshua.

9. Cornelis G. den Hertog, "Studien zur griechischen Übersetzung des Buches Josua” (Ph.D. diss., Justus-Liebig-Universität Gießen: Kohler 1996), 110-44.

10. Ibid., 110-39: "Die relative Chronologie." These parallels include Josh 5:12, which contains a cross-reference to Exod 16:35; Josh 1:13-15, which repeats almost verbatim Deut 3:18-20; as well as Josh 24:28-31 and Judg 2:6-9; and Josh 15:16-19 and Judg 1:12-15. Den Hertog argues that where the Greek translation differs from the Hebrew text but corresponds with the Greek translation of the parallel passage in the preceding book, a case for literary dependence can be made.

During the congress, Dr. Turner kindly drew my attention to her work on the date, relative and absolute, of the Greek Ezekiel: Priscilla D. M. Turner, "The Translator(s) of Ezekiel Revisited: Idiosyncratic LXX Renderings as a Clue to Inner History," in Helsinki Perspectives on the Translation Technique of the Septuagint (ed. R. Sollamo and S. Sipilä; Publications of the Finnish Exegetical Society 82; Göttingen: Vandenhoeck and Ruprecht, 2001), 279-307. Unfortunately, however, the possible influence of the Greek Joshua upon the Greek Ezekiel seems to

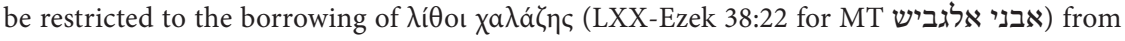
LXX-Josh 10:15, which, taken on its own, may just be a case of contextual guessing on the part of this Greek translator of Ezekiel, see also Priscilla D. M. Turner, “The Septuagint Version of Chapters I-XXXIX of the Book of Ezekiel” (Ph.D. diss., University of Oxford, 1970), 139.

11. Den Hertog, Studien, 139-44. See also Cornelis G. den Hertog, "Erwägungen zur Territorialgeschichte Koilesyriens in frühhellenistischer Zeit," ZDPV 111 (1995): 168-83.

This essay was published in XII Congress of the International Organization for Septuagint and Cognate Studies, edited by Melvin K. H. Peters, copyright (C 2006 by the Society of Biblical Literature. To purchase copies of this book, please contact SBL Customer Service by phone at 877-725-3334 [toll-free in North America] or 802-864-6185, by fax at 802-864-7626, or by visiting the online SBL Store at www.sbl-site.org. 


\section{EXTERnAl EvidenCE}

External evidence for the date and place of origin of the Greek Joshua is very scant. ${ }^{12}$ Quotations of and allusions to the Greek Joshua in the first-century C.E. compositions such as the Jewish Antiquities by Flavius Josephus, the Biblical Antiquities by Pseudo-Philo, ${ }^{13}$ Acts 7:45, Heb 4:8, ${ }^{14}$ and Conf. 166 by the Alexandrian exegete Philo, ${ }^{15}$ make clear that the Greek translation of Joshua must have originated in the pre-Christian era.

Yet traces of the Greek Joshua in pre-Christian Jewish Greek literature are hard to find. Compositions such as the works of Artapanus, Demetrius, Ezekiel the Tragedian, and so forth usually elaborate themes only from the Pentateuch. In the few cases where reference is made to the Joshua narratives, the Hebrew rather than the Greek version is reflected. This is the case with the Greek Ben Sira, the early first-century B.C.E. composition 2 Maccabees, which in 12:15 refers to the fall of Jericho, ${ }^{16}$ as well as the mid-second century B.C.E. composition $\mathrm{On}$ the Kings of Judea by Judas Maccabeus's ambassador to Rome, Eupolemos, where Joshua is only briefly mentioned. ${ }^{17}$

12. On the early history of hermeneutics based on Joshua, see Ed Noort, "Joshua: The History of Reception and Hermeneutics," in Past, Present, Future: The Deuteronomistic History and the Prophets (ed. J. C. de Moor and H. F. van Rooy; OtSt 44; Leiden: Brill, 2000), 199-215.

13. L.A.B. 23:1 has Joshua present his farewell speech in Shiloh (cf. LXX-Josh 24:1), rather than in Shechem (MT); see the introduction by Daniel J. Harrington in Charles Perrot, PierreMaurice Bogaert, and Daniel J. Harrington, Pseudo-Philon: Les antiquités bibliques 2 (SC 230; Paris: Cerf, 1976), 78. See further the commentary by Howard Jacobson, A Commentary on Pseudo-Philo's Liber Antiquitatum Biblicarum with Latin Text and English Translation (AGJU 31; Leiden: Brill, 1996), 710-11.

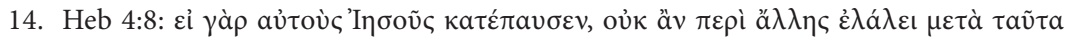

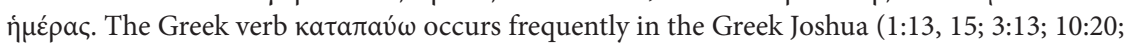
$11: 23 ; 21: 42 ; 22: 4 ; 23: 1)$.

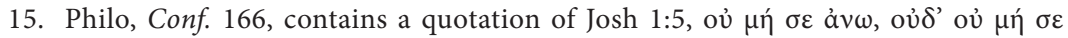

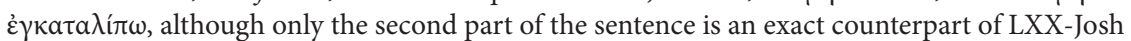

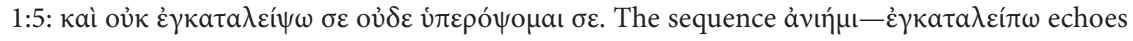

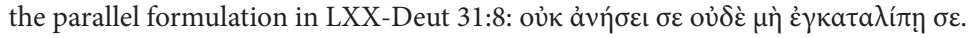

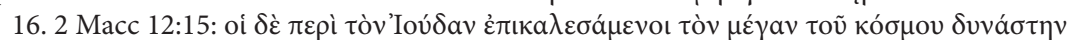

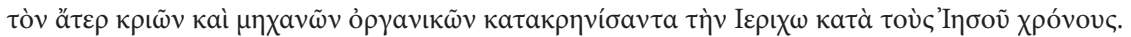
On the date of 2 Maccabees, see Jonathan A. Goldstein, 2 Maccabees (AB 41A; New York: Doubleday, 1983), 71-83.

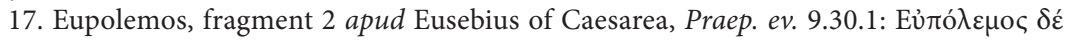

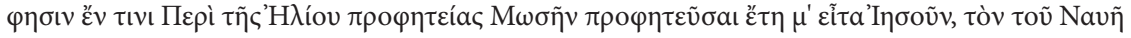

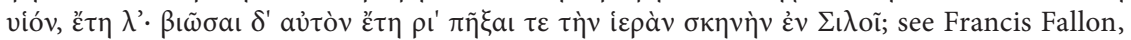
"Eupolemos," OTP 2:861-72; Carl R. Holladay, Historians (vol. 1 of Fragments from Hellenistic Jewish Authors; SBLTT Pseudepigrapha Series; Chico: Scholars Press, 1983), 93-156. The spell-

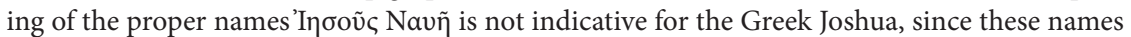
already occur in the Greek Pentateuch. Furthermore, the spelling of Shiloh as $\Sigma ı \lambda_{\mathrm{o}}$, rather than

This essay was published in XII Congress of the International Organization for Septuagint and Cognate Studies, edited by Melvin K. H. Peters, copyright $@ 2006$ by the Society of Biblical Literature. To purchase copies of this book, please contact SBL Customer Service by phone at 877-725-3334 [toll-free in North America] or 802-864-6185, by fax at 802-864-7626, or by visiting the online SBL Store at www.sbl-site.org. 
Fortunately, however, there seems to be a clear testimony to the existence of a Greek translation of Joshua as early as the first decades of the second century B.C.E., that is, in the work of the Jewish-Greek philosopher Aristobulus. According to 2 Macc 1:10, he was teacher of the young king Ptolemy VI Philometor

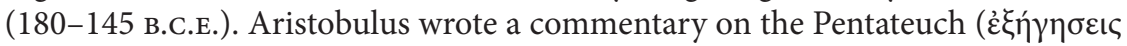
$\tau \tilde{\eta} \varsigma \mathrm{M} \omega v \sigma \varepsilon \dot{\varepsilon} \omega \gamma \rho \alpha \varphi \tilde{\eta} \varsigma)$, of which five fragments have been preserved in Eusebius of Caesarea's work Praeparatio evangelica. ${ }^{18}$ Aristobulus's work is usually dated to the years $176-170$ B.C.E. ${ }^{19}$ although this date is not undisputed. ${ }^{20}$ Of interest is fragment 3, cited in Preap. ev. 13.12, and Clement's Strom. 1.22.150:

And I will quote first the words of the Hebrew philosopher Aristobulus, which are as follows: How Aristobulus the Peripatetic, Of the Hebrews Before Us, Also Shows That the Greeks Borrowed From the Philosophy of the Hebrews; From the Addresses of Aristobulus to King Ptolemy: "It is clear that Plato followed the tra-

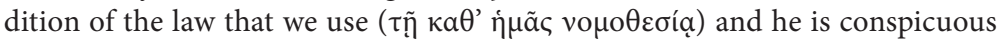
for having worked through each of the details contained in it. For it had been

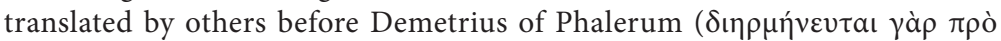

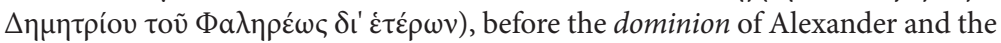

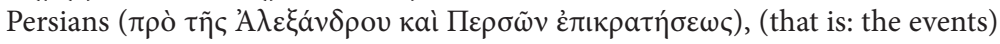

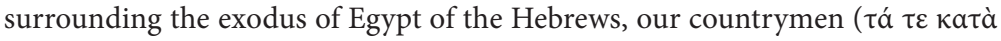

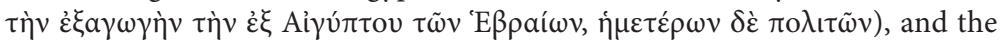

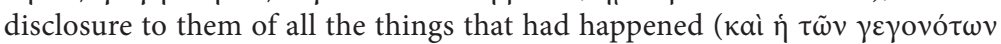

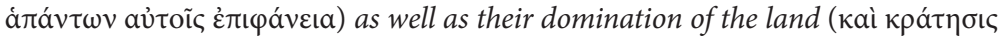

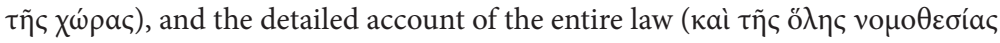

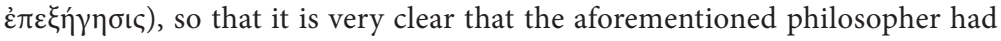
taken over many ideas; for he was very learned, just as Pythagoras, having borrowed many of the things in our traditions, found room for them in his own doctrinal system.

$\Sigma \eta \lambda \omega$ (LXX-Josh 18:1, 8, 10; 19:51; 21:2; 22:9, 12; 24:1, 25) seems to reflect the Hebrew Joshua instead of the Greek translation.

18. Adela Yabro Collins, "Aristobulus," OTP 2:831-42; Carl R. Holladay, Aristobulus (vol. 3 of Fragments of Hellenistic Jewish Authors; SBLTT Pseudepigrapha Series; Atlanta: Scholars Press, 1995).

19. Elias Bickerman, "The Septuagint as a Translation," in Proceedings of the American Academy for Jewish Research 28 (1959); repr. in Studies in Jewish and Christian History (AGJU 9.1; Leiden: Brill, 1976), 168 n. 2; Martin Hengel, Judentum und Hellenismus: Studien zu ihrer Begegnung unter besonderer Berücksichtigung Palästinas bis zur Mitte des 2.Jh.s v.Chr. (2nd ed.; WUNT 10; Tübingen: Mohr Siebeck, 1973), 295-97; Collins, "Aristobulus," 832-33; Holladay, Aristobulus, 74-75.

20. Nikolaus Walter, Der Thoraausleger Aristobulos: Untersuchungen zu seinen Fragmenten und zu pseudepigraphischen Resten der jüdisch-hellenistischen Literatur (TU 86; Berlin: Akademie, 1964), 23, dates Aristobulus much later, around 100 B.C.E.

This essay was published in XII Congress of the International Organization for Septuagint and Cognate Studies, edited by Melvin K. H. Peters, copyright $\odot 2006$ by the Society of Biblical Literature. To purchase copies of this book, please contact SBL Customer Service by phone at 877-725-3334 [toll-free in North America] or 802-864-6185, by fax at 802-864-7626, or by visiting the online SBL Store at www.sbl-site.org. 
Leaving aside the bold claim that leading Greek philosophers such as Plato and Pythagoras borrowed their insights from Jewish Scripture, it is interesting to note that, according to Aristobulus, not only the events surrounding the exodus and the law giving were translated into Greek, but also the events related to the

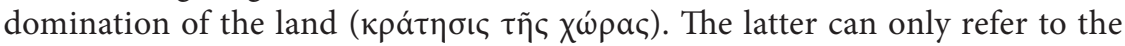
events described in the book of Joshua. ${ }^{21}$ It is interesting to note that the Greek

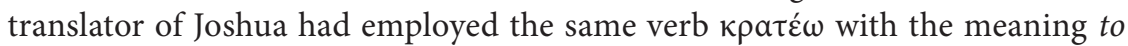
gain control over in Joshua 18:1.

The whole assembly of the sons of Israel was gathered in $\Sigma \eta \lambda \omega$, and they pitched there the tent of the testimony, and the land was dominated by them

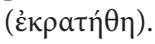

Although the use of this verb in the Greek Bible is not restricted to this place, the predominant meaning is "to grasp, to take somebody by the hand."22 Only in

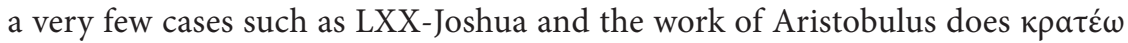
have the military sense. Gilles Dorival has made the objection that Aristobulus speaks of the translation of the law, which makes it unlikely that the phrase

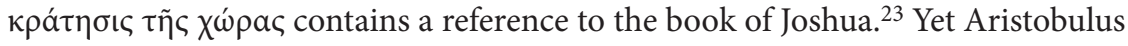

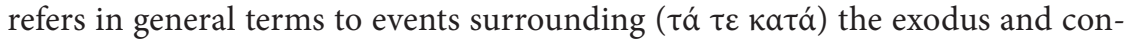
quest. The theme of the conquest of the land is irrelevant to Aristobulus's claim of Jewish superiority over the prestigious culture. It is therefore difficult to see why Aristobulus would have invented and willfully referred to a translation of the events concerning the conquest of the land.

Following this train of thought, by the time Aristobulus composed his commentary on the Pentateuch around 175 B.C.E., not only the Pentateuch but also the book of Joshua had been translated into Greek. The quotation also seems to suggest that this was the only other book of Hebrew Scripture translated into Greek by that time. It is hard to tell whether Aristobulus had no real knowledge of

21. Zacharias Frankel, Vorstudien zu der Septuaginta (Leipzig: Vogel, 1841), 17; Walter, Der Thoraausleger Aristobulos, 89 n. 1; André Pelletier, Lettre d'Aristée à Philocrate (SC 89; Paris: Cerf, 1962), 118-19.

22. Takamitsu Muraoka, A Greek-English Lexicon of the Septuagint: Chiefly on the Pentateuch and the Twelve Prophets (Louvain: Peeters, 2002), 328b. In LXX-Joshua the verb occurs only in $18: 1$. In LXX-Deut 2:34; $3: 4$, the Greek verb has the same military meaning, as is the case in 1 Esd 4:38, 40. The corresponding Hebrew verb כבש belongs to the distinctive Priestly vocabulary and links Josh 18:1 with Priestly passages in the Pentateuch, Gen 1:28 and Num 32:29; see van der Meer, Formation and Reformulation, 137-38. In these passage another Greek

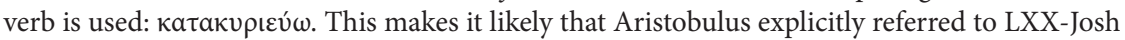
$18: 1$.

23. Gilles Dorival, "Les origines de la Septante: La traduction en grec des cinq livres de la Torah," in Dorival, Harl, Munnich, La Bible grecque des Septante, 45. See also Bickerman, "Septuagint as Translation," 172 n. 13. Den Hertog, Studien, 139 n. 69, follows Dorival.

\footnotetext{
This essay was published in XII Congress of the International Organization for Septuagint and Cognate Studies, edited by Melvin K. H. Peters, copyright @ 2006 by the Society of Biblical Literature. To purchase copies of this book, please contact SBL Customer Service by phone at 877-725-3334 [toll-free in North America] or 802-864-6185, by fax at 802-864-7626, or by visiting the online SBL Store at www.sbl-site.org.
} 
the origin and date of this Greek Hexateuch or deliberately concealed that knowledge. This statement seems to me to be clear proof of the existence of a Greek translation of Joshua as early as the beginning of the second century в.C.E.

\section{Internal Evidence: THe Toponyms}

Unfortunately, all other clues regarding the date and provenance of the Greek Joshua must derive from the translation itself. Unlike the Greek versions of prophetical books such as Isaiah and Daniel, the Greek Joshua never hints at contemporary events. ${ }^{24}$ In the few cases where the Hebrew version of Joshua does point to future events, as is the case with the curse over the person who will try to rebuild Jericho (Josh 6:26), the outstanding conquest of Gezer (16:10), and the predicted apostasy of Israel (Josh 23), the Greek version complements the texts with material from 1 Kings (16:34; 9:16 in LXX-Josh 6:26a and 16:10a, respectively) or Judges (1:1-3:6 in LXX-Josh 24:33a-b). Apparently the aim of these additions is to make clear that the fulfillment of these open ends in the book of Joshua already took place in the narrated time of Joshua itself and belonged to the same distant past as the primitive custom of circumcising people with flint knives (LXX-Josh 5:2-3; 21:42d; 24:31a). ${ }^{25}$ The focus of the Greek translator is on the past, not on his own present or future. Eschatological themes as introduced in the Greek Isaiah and Daniel are alien to the Greek Joshua. ${ }^{26}$

Yet it might be asked whether the Greek Joshua unconsciously reflects the political situation of a given period. Here the work of den Hertog deserves special mention. Den Hertog takes his clues from nonliteral translations or transliterations of geographical names in the book. Thus the Greek names for the districts

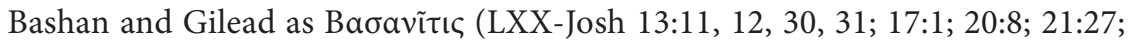

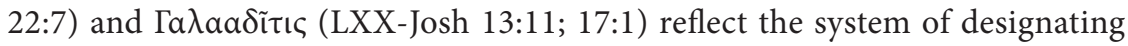
areas with Semitic names by adding the ending -ĩ $\iota \varsigma$, introduced under Ptolemaic

24. Isac L. Seeligmann, The Septuagint Version of Isaiah: A Discussion of Its Problems (Mededelingen en verhandelingen van het vooraziatisch genootschap "Ex Oriente Lux" 9; Leiden: Brill, 1948); Arie van der Kooij, Die alten Textzeugen des Jesajabuches: Ein Beitrag zur Textgeschichte des Alten Testaments (OBO 35; Fribourg: Universitätsverlag; Göttingen: Vandenhoeck \& Ruprecht, 1981).

25. Van der Meer, Formation and Reformulation, 337-39.

26. Den Hertog, Studien, 183; Cornelis G. den Hertog, "Eschatologisierung in der griechischen Übersetzung des Buches Josua," in The New Things: Eschatology in Old Testament Prophecy: Festschrift for Henk Leene (ed. F. Postma, K. Spronk, and E. Talstra; Amsterdamse Cahiers voor Exegese van de Bijbel en Zijn Tradities Supplement Series 3; Maastricht: Shaker,

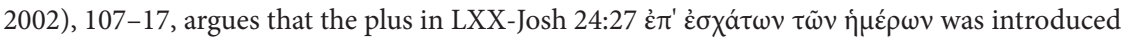
for eschatological reasons, but then he redefines eschatology as paraenesis (113). To my mind, LXX-Josh 24:27 offers a harmonization with Deut 31:29 rather than a midrash-type eschatologization of that passage.

This essay was published in XII Congress of the International Organization for Septuagint and Cognate Studies, edited by Melvin K. H. Peters, copyright @ 2006 by the Society of Biblical Literature. To purchase copies of this book, please contact SBL Customer Service by phone at 877-725-3334 [toll-free in North America] or 802-864-6185, by fax at 802-864-7626, or by visiting the online SBL Store at www.sbl-site.org. 
rule, and thus point to 285 B.C.E. as terminus post quem..$^{27}$ The unspecified use of

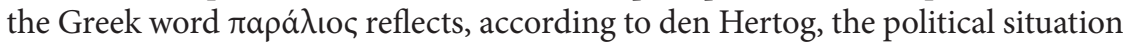
in Palestine before the Seleucid reorganization of Palestinian administration in 198 B.C.E. As a result of that reorganization, the Greek word came to be used for a new district along the coast: Пара入ía. ${ }^{28}$ Furthermore, den Hertog finds evidence for an Alexandrian provenance of the Greek Joshua in the use of the Greek

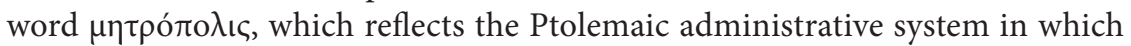
the metropolis was the technical term for the center of a nomos. ${ }^{29}$

Nevertheless, the information provided by the Greek renderings of Palestinian toponyms is, according to den Hertog, only of limited value, since a number of Greek renderings seem to reveal the lack of precise knowledge of Palestinian topography. Den Hertog points to the Greek translator's invention of a district

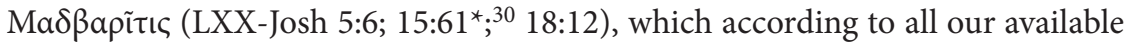
data existed only in the mind of the Greek translator. ${ }^{31}$ Lack of precise topographical knowledge is, according to den Hertog, the source of the confusion in LXX-Josh

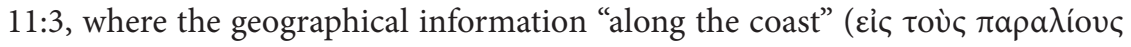
Xavavaíovৎ) and "from the east" (åmò ảvato $\lambda \tilde{\omega} v$ ) contains an inner contradiction. Especially this example seems to undermine the value of the use of Greek rapá $\lambda_{\text {Io }}$ as argument for a pre-198 B.C.E. date of the Greek Joshua. Unlike the Greek translations of the prophetical books and the translation produced by Symmachus, the Greek Joshua makes sparse use of Hellenized toponyms and does not, for instance,

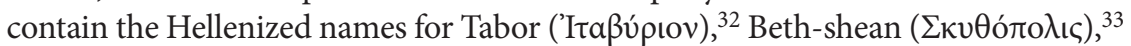

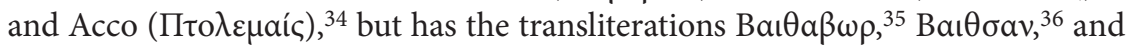

27. Den Hertog, Studien, 139-40.

28. Ibid., 141-42.

29. Ibid., 142-43.

30. The reading $\beta a \delta \delta a \rho \gamma ı \varsigma$ in Codex Vaticanus, adopted by Alfred Rahlfs, Septuaginta: Id est Vetus Testamentum graece iuxta LXX interpretes (Stuttgart: Deutsche Bibelgesellschaft, 1935)

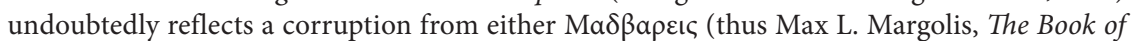
Joshua in Greek according to the Critically Restored Text with an Apparatus Containing the Variants of the Principal Recensions and of the Individual Witnesses [Publications of the Alexander Kohut Memorial Foundation parts 1-4; Paris: Geuthner, 1931-1938; part 5, ed. E. Tov; Phila-

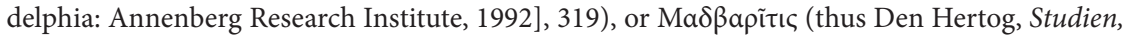
86). See van der Meer, Formation and Reformulation, 22-32, for the questions concerning the critical reconstruction of the original text of LXX-Joshua.

31. Van der Meer, Formation and Reformulation, 355-59.

32. Cf LXX-Hos 5:1; LXX-Jer 26[46]:18.

33. Cf. 2 Macc 12:30.

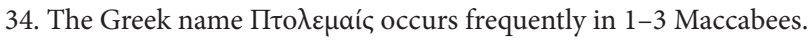

35. Baı $\theta \alpha \beta \omega \rho$ is Margolis's reconstruction of the Greek rendering of בתבור in Josh 19:22 (Book of Joshua in Greek, 373).

36. LXX-Josh 17:11, 16.

This essay was published in XII Congress of the International Organization for Septuagint and Cognate Studies, edited by Melvin K. H. Peters, copyright ( $\odot 2006$ by the Society of Biblical Literature. To purchase copies of this book, please contact SBL Customer Service by phone at 877-725-3334 [toll-free in North America] or 802-864-6185, by fax at 802-864-7626, or by visiting the online SBL Store at www.sbl-site.org. 


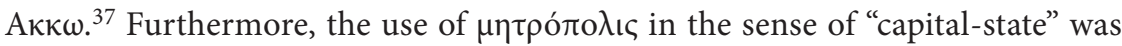
not restricted to Ptolemaic Egypt. ${ }^{38}$

Thus it would seem that the geographical information does not provide solid proof for a third-century B.C.E. date of the Greek Joshua, especially since the Greek translator seems to have had only a limited knowledge of Palestinian topography. Yet a careful study of the Greek version in its own right and within the context of contemporary sources makes clear that his knowledge of Palestinian topography was better than hitherto assumed. For example, LXX-Josh 5:12 seems to contain another puzzling and contradictory statement: the area around Jericho seems to be called the country of the Phoenicians ( $\chi \omega \dot{\omega} \rho \alpha \tau \tilde{\omega} v$ Фoเví $\kappa \omega v)$, which is

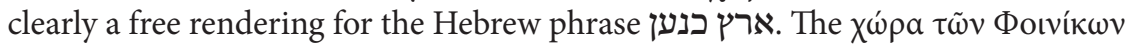
designates the area around the Phoenician city-states Sidon and Tyre north of Palestine, not such a remote inland oasis. The text makes an explicit reference to Exod 16:35, where the same Hebrew expression ארץ כנען occurs and where the Greek Exodus has the condensed rendering $\dot{\eta}$ Фоเvıкฑ. Unlike the Hebrew and Greek texts of Exodus, where the land of Canaan or Phoenicia remains rather vague, the Greek expression $\chi \omega \dot{\omega} \rho \alpha \tau \tilde{\omega} v$ Фoเvík $\omega v$ is inappropriate, since the text refers to the neighborhood of Jericho, whereas the Greek name Phoenicia usually refers to the contemporary state of Lebanon. According to den Hertog, the unusual Greek rendering in Josh 5:12 is best explained as a case of literary dependence of the Greek Joshua upon the Greek Pentateuch, ${ }^{39}$ but in that case one would have expected exactly the same phrase, í Фoเvıки́, in LXX-Joshua as well.

As I have attempted to demonstrate in my dissertation, the Greek Joshua probably did not intend to associate Jericho with the far more northern land of the Phoenicians but wanted to describe Jericho's neighborhood as the country

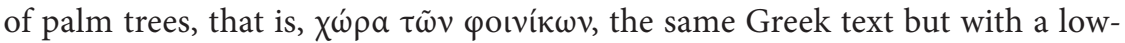
ercase letter $\varphi^{40}$ Other literary initiatives employed by the Greek translator in these verses, such as the detailed description of the location of Jericho (5:10) $\dot{\varepsilon} \pi \mathrm{i}$

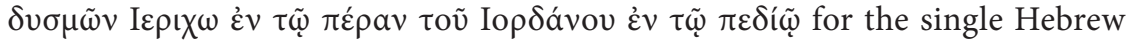
expression בערבות יריחו, cast doubts on the idea that the Greek translator of Joshua had no intimate knowledge of Palestinian topography, at least not for this part of Palestine.

This rendering is also interesting for another reason. The area around Jericho with its palm groves and balsam plantations must have had high economical value for the Ptolemies. ${ }^{41}$ It is probably no coincidence, so den Hertog, that Jericho

37. Den Hertog, Studien, 143-44.

38. LSJ 1131b; see, e.g., Xenophon, Anab. 5.2.3.

39. Den Hertog, Studien, 113-14.

40. Van der Meer, Formation and Reformulation, 400-408. See also Theophrastus, Enquiry into Plants 2.6.8.

41. Hengel, Judentum und Hellenismus, 86-92.

This essay was published in XII Congress of the International Organization for Septuagint and Cognate Studies, edited by Melvin K. H. Peters, copyright $\odot 2006$ by the Society of Biblical Literature. To purchase copies of this book, please contact SBL Customer Service by phone at 877-725-3334 [toll-free in North America] or 802-864-6185, by fax at 802-864-7626, or by visiting the online SBL Store at www.sbl-site.org. 
occurs in the Zenon archive, a collection of documentary papyri from the middle of the third century B.C.E. ${ }^{42}$ Between 260 and 258 B.C.E., Zenon, a young assistant

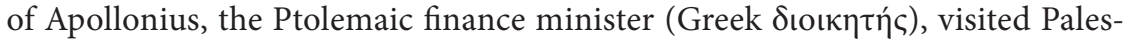
tine a few times and kept records in his personal archive in the Egyptian Faiyum. His archive consists of some two thousand documents. On his journeys he was accompanied by personnel such as cooks, scribes, and mule drivers (P.Lond. 7, 1930). His archive constitutes practically our sole source of information concerning Palestine in the third century B.C.E. Therefore it is interesting to compare the place names found in this archive with the place names in the Greek Joshua.

\begin{tabular}{|c|c|c|c|}
\hline Name & Zenon archive & LXX-Joshua & Other Sources \\
\hline $\begin{array}{l}\text { Abel- } \\
\text { shittim? }\end{array}$ & $A \beta \varepsilon \lambda \lambda \alpha^{43}$ & $\left(2: 1 \sum \alpha \tau \tau \iota v\right)$ & \\
\hline Acco & $\Pi \tau o \lambda \varepsilon \mu a i \varsigma^{44}$ & 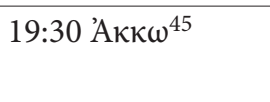 & 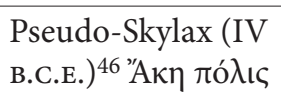 \\
\hline Ascalon & 'Aбкád $\omega v^{47}$ & 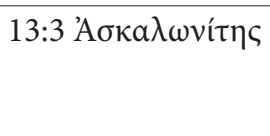 & 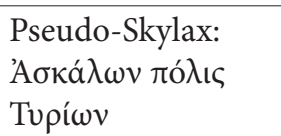 \\
\hline
\end{tabular}

42. Den Hertog, Studien, 143 n. 80.

43. P.Cair.Zen. 59004, line 5; P.Lond. 7, 1930, line 171; cf. Xavier Durand, Des grecs en Palestine au 3e siècle avant Jésus-Christ: Le dossier syrien des archives de Zénon de Caunos (261-252) (Cahiers de la revue biblique 38; Paris: Gabalda, 1997), 63.

44. P.Cair.Zen. 59004, line 12; 59008, line 17; P.Cair.Zen. 59558 line 3; 59698, lines 11.25; Pap.Lugd.Bat. 20, 32, line 4; P.Lond. 7, 2022, line 1; 2141, line 2; P.Mich.Zen. 1, 3; PSI 4, 406, line 14; PSI 5, 495, line 13; PSI 6, 616, line 13; see Pieter W. Pestman, A Guide to the Zenon Archive (P.L.Bat.21) (Papyrologica Lugduno-Batava 21b; Leiden: Brill, 1981), 496.

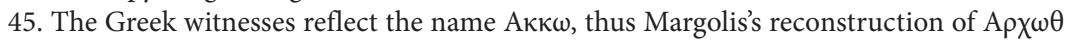
E (B.55.129.Sah.Eth; cf. 120 A $\rho \chi \omega \beta)<A \kappa \kappa \omega \beta \underline{\text { S }}$ (54; cf. 75 A $\omega \beta$, VetLat Achob; 44.106.134

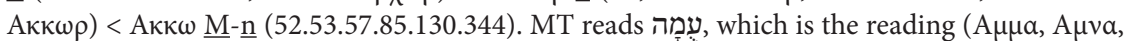
$\mathrm{A} \mu \alpha$, and $\mathrm{R}$ Syh) found in the $\underline{\mathrm{P}}$ and $\underline{\mathrm{C}}$ witnesses. MT is usually regarded as a corruption from עכו; cf. Judg 1:31; see, e.g., Johannes Hollenberg, "Zur Textkritik des Buches Josua und des Buches der Richter," ZAW 1 (1881): 97-105, esp. 100-101; Martin Noth, Das Buch Josua (2nd ed.; HAT 1.7; Tübingen: Mohr Siebeck, 1953), 114; J. Alberto Soggin, Le livre de Josué (CAT 5a; Neuchâtel: Delachaux \& Niestlé, 1970), 143; Dominique Barthélemy, Josué, Juges, Ruth, Samuel, Rois, Chroniques, Esdras, Néhémie, Esther (vol. 1. of Critique textuelle de l'Ancien Testament (OBO 50.1; Fribourg: Universitätsverlag; Göttingen: Vandenhoeck \& Rupprecht, 1982), 57-59; Trent C. Butler, The Book of Joshua (WBC 7; Waco, Tex.: Word, 1983), 199; and Volkmar Fritz, Das Buch Josua (HAT 1.7; Tübingen: Mohr Siebeck, 1994), 194.

46. Menahem Stern, Appendices and Indexes (vol. 3 of Greek and Latin Authors on Jews and Judaism: Edited with Introduction, Translations and Commentary; Jerusalem: Israel Academy of Sciences and Humanities, 1984), 8-12.

47. P.Cair.Zen. 59010, line 22.

\footnotetext{
This essay was published in XII Congress of the International Organization for Septuagint and Cognate Studies, edited by Melvin K. H. Peters, copyright @ 2006 by the Society of Biblical Literature. To purchase copies of this book, please contact SBL Customer Service by phone at 877-725-3334 [toll-free in North America] or 802-864-6185, by fax at $802-864-7626$, or by visiting the online SBL Store at www.sbl-site.org.
} 
VAN DER MEER: PROVENANCE, PROFILE, \& PURPOSE OF JOSHUA

\begin{tabular}{|c|c|c|c|}
\hline $\begin{array}{l}\text { Hauran- } \\
\text { Aurana }\end{array}$ & Aüpava & - & $\begin{array}{l}1 \text { Macc 6:43 Aúpav; } \\
2 \text { Macc 4:40 } \\
\text { Aúpavóc; Ezek 47:16 } \\
\text { Aúpaveĩ } 16\end{array}$ \\
\hline Beth-anath & 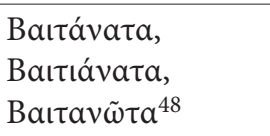 & 19:38 Baı $\theta a v a \theta^{49}$ & 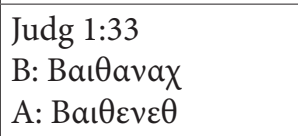 \\
\hline $\begin{array}{l}\text { Edom- } \\
\text { Idumea }\end{array}$ & 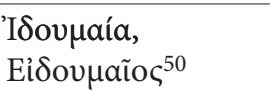 & 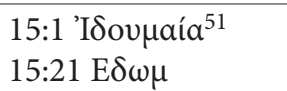 & \\
\hline Eitoui? & Eítout $^{52}$ & - & \\
\hline Galilee & 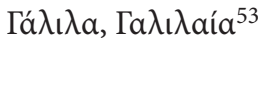 & 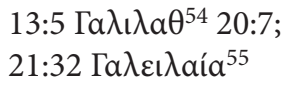 & \\
\hline Gaza & Га́弓а & 13:3 Гаگа̃̃os & \\
\hline Jaffa & 'Іо́лฤ & 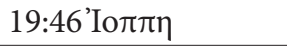 & \\
\hline $\begin{array}{l}\text { Jamnia- } \\
\text { Yabneh }\end{array}$ & 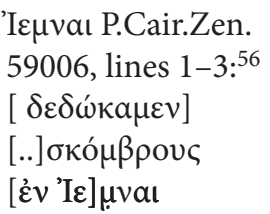 & $15: 46$ I $\varepsilon \mu \nu \alpha \mathrm{i}^{57}$ & 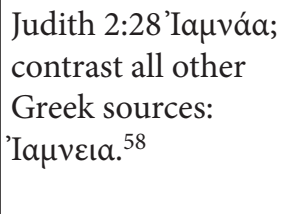 \\
\hline
\end{tabular}

48. P.Cair.Zen. 59004, line 10; 59011, line 8; P.Lond. 7, 1948, lines 4, 13; PSI 6, 594, line 18.

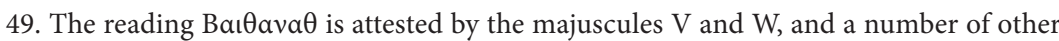
witnesses, and furthermore reflected by the variant readings. Margolis conjectured Bai $\theta$ Ave $\theta$.

50. P.Cair.Zen. 59015, verso line 42; Pap.Lugd.Bat. 20, 18, line 3.

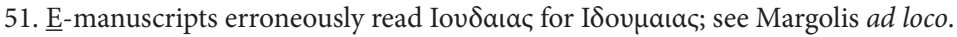

52. Mentioned only in P.Cair.Zen. 59004; see Durand, Des grecs, 67.

53. P.Col.Zen. 12 , lines 18, 22.

54. Rahlfs adopted the reading of A.G.V.W.15.82.344(mg).85(mg).29.On-ed the reading $\Gamma \alpha \beta \lambda_{\iota}$. Margolis reconstructed $\Gamma \alpha \lambda_{\iota} \lambda \alpha \theta$ on the basis of his $\underline{S}$ witnesses, from which the $\underline{E}$ (B.407) reading $\Gamma \alpha \lambda_{\iota} \alpha \theta$ would be a secondary corruption; cf. $\Gamma a \lambda \iota a \delta 120$.Aeth. Cf. Johannes Hollenberg, Der Charakter der alexandrinischen Uebersetzung des Buches Josua und ihr textkritischer Werth

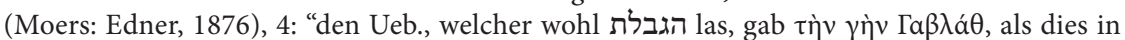
Гàıá $\theta$ verdorben war, wollte ein Abschreiber durch Angabe der philistäischen Herkunft Goliaths seine Bibelkenntnis zeigen."

55. Гa $\lambda \varepsilon$ เı aía in 12:23 B.120.407 probably reflects a scribal error; see Margolis ad loco.

56. See Pestman, Guide to the Zenon Archive, 486; Durand, Des grecs, 94-97.

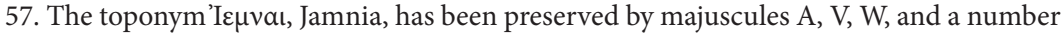

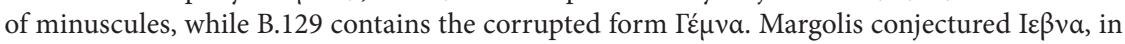
order to adapt the Greek name to the Hebrew יבנה, but this reconstruction fails to do justice to the papyrological evidence.

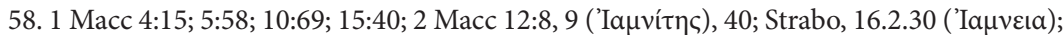
Josephus, Life 188.1; Ant. 12.308 ('Ia $\mu v \varepsilon ı$ ); Herennius Philo fragment 3c 790, F.7.5 and F.38.1

\footnotetext{
This essay was published in XII Congress of the International Organization for Septuagint and Cognate Studies, edited by Melvin K. H. Peters, copyright (C 2006 by the Society of Biblical Literature. To purchase copies of this book, please contact SBL Customer Service by phone at 877-725-3334 [toll-free in North America] or 802-864-6185, by fax at 802-864-7626, or by visiting the online SBL Store at www.sbl-site.org.
} 


\begin{tabular}{|c|c|c|c|}
\hline Jericho & ${ }^{\circ} \mathrm{E} \rho \chi \chi \omega^{59}$ & 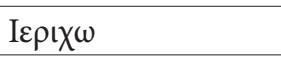 & \\
\hline Jerusalem & 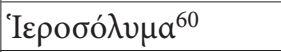 & 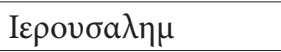 & \\
\hline Kadesh & 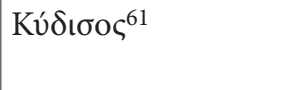 & 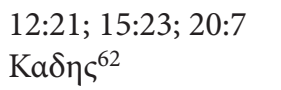 & \\
\hline Lakasa? & $\Lambda a ́ k a \sigma \alpha^{63}$ & - & \\
\hline Mareshah & Mápı $\sigma \alpha, M a \rho i ́ \zeta \alpha^{64}$ & 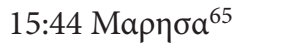 & \\
\hline Moab & $M \omega \beta i ́ \tau \eta \varsigma^{66}$ & 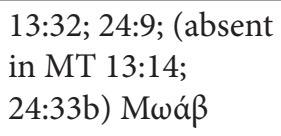 & $\begin{array}{l}\text { contrast } \\
M \omega \alpha \beta \varepsilon[\iota] \tau \iota \varsigma^{67}\end{array}$ \\
\hline Noe? & Nón ${ }^{68}$ & - & - \\
\hline $\begin{array}{l}\text { Pegai? } \\
\text { Afek? }\end{array}$ & 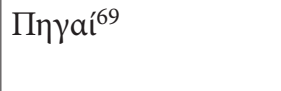 & & Ant. 13.260 \\
\hline $\begin{array}{l}\text { Rabbat- } \\
\text { Amman }\end{array}$ & 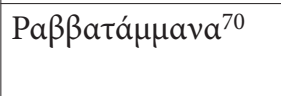 & $13: 25 \mathrm{P} \alpha \beta \beta \alpha$ & 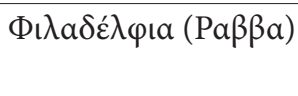 \\
\hline Sourabitta? & $\begin{array}{l}\sum \omega \rho a ́ \beta ı \tau \tau a, \\
\sum o v \rho a ́ \beta ı \tau \alpha^{71}\end{array}$ & - & - \\
\hline $\begin{array}{l}\text { Straton's } \\
\text { tower- } \\
\text { Caesarea }\end{array}$ & $\Sigma \tau \rho a ́ \tau \omega \nu 0 \varsigma \pi v ́ \rho \gamma \circ \varsigma$ & - & \\
\hline
\end{tabular}

Although the names for Palestinian towns and regions in the Zenon archive

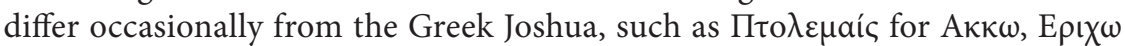

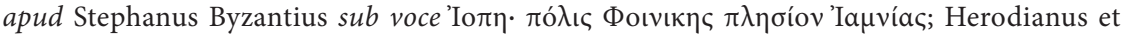
Pseudo-Herodi, De prosodia catholica 3.1.248.16; 3.1.339.5; 3,1.531.18.

59. P.Cair.Zen. 59004, line 4; Durand, Des grecs, 63.

60. P.Cair.Zen. 59004, line 3; 59005, line 6.

61. P.Cair.Zen. 59004, line 11; Pap.Lugd.Bat. 20, 32; line 12.

62. P.Cair.Zen. 59004, line 11; Pap.Lugd.Bat. 20, 32, line 12; LXX-Josh 12:21; 15:23; 20:7; Durand, Des grecs, 68-69.

63. Mentioned only in P.Cair.Zen. 59004, line 7; see Durand, Des grecs, 65-66.

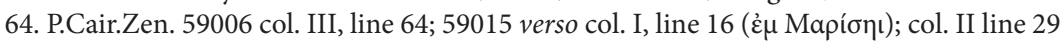

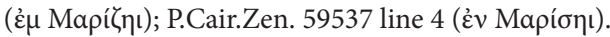

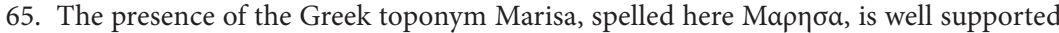
by witnesses of the $\underline{S}, \underline{M}$ and $\underline{C}$ families (A.V.W. Arm, $S^{\mathrm{C}}{ }^{\mathrm{C}}$, VetLat, Syh).

66. P.Cair.Zen. 59009, line 22.

67. Gen 19:37; Exod 15:15; Deut 2:9; 1 Chr 18:2; Isa 15:1, 1, 2, 4, 5, 8; 16:7; 25:10; Jer $31[48]: 33 ; 32: 7$ [25:21].

68. Mentioned only in P.Cair.Zen. 59004, line 8; see Durand, Des grecs, 66.

69. PSI 4, 406, line 12.

70. PSI 6, 616, line 27.

71. P.Cair.Zen. 59004, line 6; P.Lond. 7, 1930, line 175; Durand, Des grecs, 63-65.

\footnotetext{
This essay was published in XII Congress of the International Organization for Septuagint and Cognate Studies, edited by Melvin K. H. Peters, copyright (๑ 2006 by the Society of Biblical Literature. To purchase copies of this book, please contact SBL Customer Service by phone at 877-725-3334 [toll-free in North America] or 802-864-6185, by fax at 802-864-7626, or by visiting the online SBL Store at www.sbl-site.org.
} 


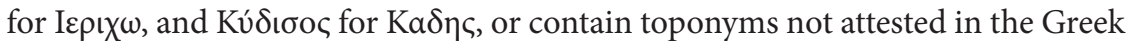
Joshua, such as $\Sigma \tau \rho a ́ \tau \omega v o \varsigma ~ \pi u ́ \rho \gamma o \varsigma$ (Caesarea) and the unknown Transjordan

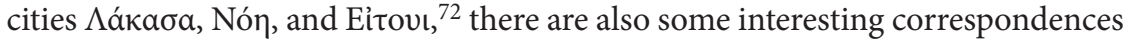
between the two lists:

(1) Both the Greek Joshua and the Zenon papyri contain variable spellings of the same name; see, for instance, the spelling of Edom and Galilee. In one and the same document (P.Cair.Zen. 59015) we find Mareshah spelled with a sigma and with a zèta.

(2) Although Acco bears the Hellenized name Ptolemais in the Zenon letters, the capital of Ammon, which was renamed by Ptolemy II Philadelphos, ${ }^{73}$

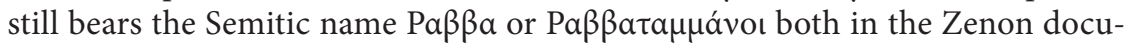
ments and the Greek Joshua. While the Semitic name continued to be used in Jewish Greek writings from later periods ${ }^{74}$ and also occurs in Polybius 5.71.4, it is interesting to note that the Greek Joshua agrees with the Zenon documents vis-àvis most other references to the Ammonite capital in Greek writings. ${ }^{75}$

(3) Even more remarkable is the almost exclusive link between the Greek Joshua and the Zenon archive when it comes to the spelling of the city of Yabneh-

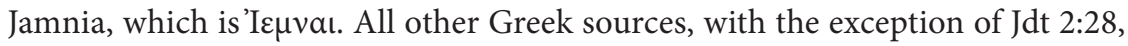
spell the name as 'Ia $\mu v \varepsilon i ́ a$, which is clearly different from the reading found in LXX-Josh 15:46 and the Cairo Zenon papyrus number 6.

Unfortunately, however, both the papyrological and manuscript evidence is based on reconstruction. The first lines of a fragmentary column (P.Cair.Zen.

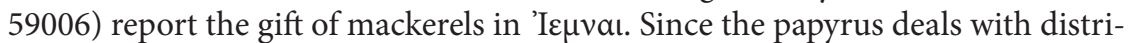
bution of fish during Zenon's tour in Idumea and mentions the neighboring places

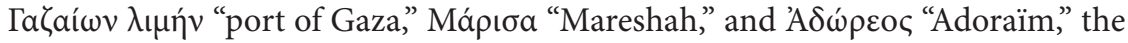

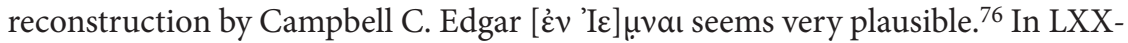

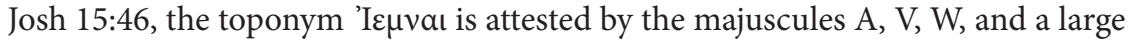

72. Mentioned only in P.Cair.Zen. 59004; see Durand, Des grecs, 65-67.

73. Günther Hölbl, Geschichte des Ptolemäerreiches: Politik, Ideologie und religiöser Kultur von Alexander dem Großen bis zur römischen Eroberung (Darmstadt: Wissenschaftliche Buchgesellschaft 1994), 60.

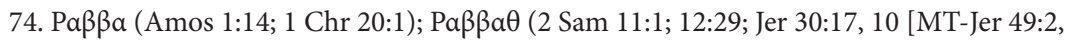

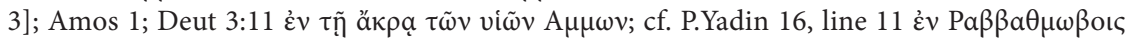

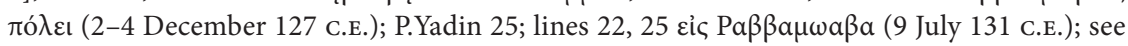
Naphtali Lewis, ed., The Documents from the Bar Kochba Period in the Cave of Letters: Greek Papyri (Judean Desert Studies 2; Jerusalem: Israel Exploration Society, 1989).

75. See already the work of the second-century B.c.E. historian Posidonius 1052003 2a, 87, F. 70.9, and further, e.g., Strabo, 16.760, Josephus, J.W 2.458; Ant. 20.2, and the New Testament.

76. Campbell C. Edgar, Zenon Papyri: Catalogue général des Antiquités Égyptiennes du Musée du Caire. 1. 59001-59139 (Cairo: Imprimerie de l'institut français d’archéologie orientale, 1925), 11.

This essay was published in XII Congress of the International Organization for Septuagint and Cognate Studies, edited by Melvin K. H. Peters, copyright @ 2006 by the Society of Biblical Literature. To purchase copies of this book, please contact SBL Customer Service by phone at 877-725-3334 [toll-free in North America] or 802-864-6185, by fax at 802-864-7626, or by visiting the online SBL Store at www.sbl-site.org. 


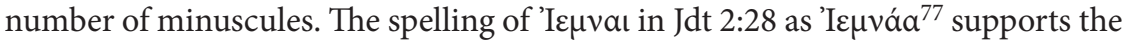
reconstruction in both the papyrus and the Greek Joshua.

A further complication is posed by the fact that the MT has a different text: "from Ekron and to the sea," which makes perfect sense in the Hebrew text. ${ }^{78}$ Since the cities listed in Josh 15:45-47, Ekron and Ashdod, are in close proximity to Jamnia, the Greek translator in all likelihood introduced this city into his Greek translation, probably unaware of the fact that the proper Hebrew name for Jamnia, Yabneh or Yabneh-El, was mentioned already elsewhere

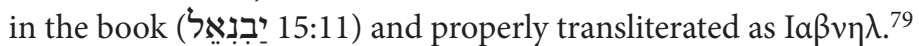

The geographical evidence is not very conclusive and does not provide solid proof for a third-century B.C.E. provenance of the Greek Joshua. Yet it might be suggested that the correspondence with respect to the names of Rabbat and Yabneh-Jamnia lends support to the thesis that the Greek Joshua was made in the third century B.C.E. The fluidity in the spelling of the toponyms, observable both in the Zenon papyri and the Greek Joshua, may also point to a relatively early date of the Greek Joshua. Perhaps the Greek translator's creation of the fictive district Madbaritis also reflects the time in which the Hellenization of Palestinian toponyms was still in its early stages. Apparently the Greek translator had more geographical knowledge of Palestine than usually assumed.

\section{The Profile of the Greek Translator}

This brings me to the next issue: the competences of the Greek translator. As Arie van der Kooij has demonstrated in several studies, the Greek translators of the biblical books, the book of Joshua not excluded, must have belonged to learned, scribal circles, capable of reading aloud the text (å $\left.{ }^{2} \gamma v \omega \sigma \iota \varsigma\right)$, interpreting it

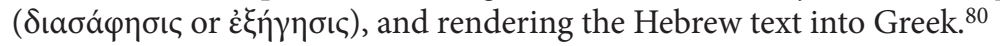

77. Thus Hanhart's reconstruction : Robert Hanhart, Iudith (Septuaginta Vetus Testamentum graecum auctoritate academiae scientiarum Gottingensis editum 8.4; Göttingen: Vandenhoeck \& Ruprecht, 1979).

78. See the discussion in Jacobus C. de Vos, Das Los Judas: Über Entstehung und Ziele der Landbeschreibung in Josua 15 (VTSup 95; Leiden: Brill, 2003), 63-64.

79. Thus A. G. W rell. Margolis conjecturally reconstructed Is $\beta$ van $\lambda$.

80. Arie van der Kooij, The Oracle of Tyre: The Septuagint of Isaiah 23 as Version and Vision (VTSup 71; Leiden: Brill, 1998), 112-23; idem, "Perspectives on the Study of the Septuagint: Who Are the Translators?" in Perspectives in the Study of the Old Testament and Early Judaism: A Symposium in Honour of Adam S. van der Woude on the Occasion of His 70th Birthday (ed. F. García Martínez and E. Noort; VTSup 73; Leiden: Brill, 1998), 214-29; idem, "Zur Frage der Exegese im LXX-Psalter: Ein Beitrag zur Verhältnisbestimmung zwischen Original und Übersetzung," in Der Septuaginta-Psalter und seine Tochterübersetzungen: Symposium in Göttingen 1997 (ed. A. Aejmelaeus and U. Quast; MSU 24; Göttingen: Vandenhoeck \& Ruprecht, 2000), 366-79.

\footnotetext{
This essay was published in XII Congress of the International Organization for Septuagint and Cognate Studies, edited by Melvin K. H. Peters, copyright @ 2006 by the Society of Biblical Literature. To purchase copies of this book, please contact SBL Customer Service by phone at 877-725-3334 [toll-free in North America] or 802-864-6185, by fax at 802-864-7626, or by visiting the online SBL Store at www.sbl-site.org.
} 
Already in 1876 Johannes Hollenberg had demonstrated that the Greek translator of Joshua possessed to a large extent the ability to read and interpret classical Hebrew and to render it into good Greek. ${ }^{81}$ In the Qumran era the competence of the Greek translator of Joshua was played down in favor of the still-popular idea that the Greek translation reflects a recensionally different and older Hebrew version of the book of Joshua, ${ }^{82}$ which in my view is only true for chapter 20 . As I have attempted to demonstrate in my book Formation and Reformulation, the Greek version abounds with small literary initiatives, which render it impossible that the Greek translator was an ordinary dragoman without intimate knowledge of the entire book.

A study of the Greek vocabulary, ${ }^{83}$ which is almost twice as large as that of the Hebrew text, ${ }^{84}$ as well as the Greek syntax, which contains relatively more genuine Greek constructions than later books ${ }^{85}$ makes clear that the translator had a full command of the Greek language. Even more remarkable is his intimate knowledge of classical Hebrew, which contains only a very restricted amount of deficiencies. ${ }^{86}$ Already in the third century B.C.E. it was far from self-evident that educated Jews in Ptolemaic Egypt possessed good knowledge of classical Hebrew, as the example of Demetrius the chronographer makes clear. The Egyptian Jewish vernacular language was either Aramaic or Greek, as attested by the papyri and inscriptions. ${ }^{87}$

81. Hollenberg, Der Charakter; van der Meer, Formation and Reformulation, $32 \mathrm{ff}$.

82. See, e.g., Samuel Holmes, Joshua: The Hebrew and Greek Texts (Cambridge: Cambridge University Press, 1914).

83. See Jacqueline Moatti-Fine, Jésus (Josué) : Traduction du texte grec de la Septante : Introduction et notes (La bible d'Alexandrie 6; Paris: Cerf, 1996), 42-68.

84. J. Bajard and R.-Ferdinand Poswick, "Aspects statistiques des rapports entre la Septante et le texte massorétique," in VII Congress of the International Organization for Septuagint and Cognate Studies: Leuven, 1989 (ed. C. Cox; SBLSCS 31; Atlanta: Scholars Press, 1991), 123-56.

85. For instance, the Greek translator's use of the participium coniunctum in Josh 1:11; 5:13; 24:9; the genetivus absolutus in 4:23; 6:5; and the ö $\tau$ r recitativum in 4:22; see Sipilä, Between Literalness and Freedom.

86. Hollenberg, Der Charakter, 9-11. Whereas the Greek translators of Exodus (13:18) and Judges (7:11) struggled with the meaning of חמש Qal, the Greek translator provided

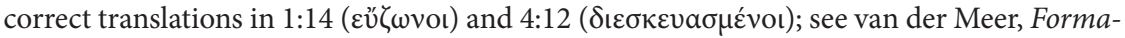
tion and Reformulation, 243-44.

87. Bezalel Porten and Ada Yardeni, eds., Textbook of Aramaic Documents (Jerusalem: Hebrew University; Winona Lake, Ind.: Eisenbrauns, 1986-1999); Victor A. Tcherikover, Alexander Fuks, Menahem Stern, and David M. Lewis, eds., Corpus papyrorum judaicarum (Cambridge: Harvard University Press 1957-1964) = CPJ; to be supplemented by the papyri listed by Isaac F. Fikhman, "Létat des travaux au 'Corpus Papyrorum Judaicarum' IV," in Akten des 21. internationalen Papyrologenkongresses, Berlin 13-19.8.1995 (ed. B. Kramer, W. Luppe, H. Maehler, and G. Poethke; Stuttgart: Teubner, 1997), 290-96; and the archive of the Jewish

This essay was published in XII Congress of the International Organization for Septuagint and Cognate Studies, edited by Melvin K. H. Peters, copyright $\odot 2006$ by the Society of Biblical Literature. To purchase copies of this book, please contact SBL Customer Service by phone at 877-725-3334 [toll-free in North America] or 802-864-6185, by fax at 802-864-7626, or by visiting the online SBL Store at www.sbl-site.org. 
Besides his knowledge of classical Hebrew and Greek, the Greek translator must have had a very good knowledge of the Pentateuch. On several occasions he departed from the Hebrew text in order to adjust the text of Joshua to the Pentateuch. The use of the Greek verb rapatá $\sigma \sigma \omega$ "to draw up in battle order," for Hebrew לחם "to fight" in Josh 24:9, is one example: after all, Balak did not really come to a fight with Israel, which made a literal rendering of the Hebrew verb by $\pi \mathrm{o} \lambda \varepsilon \mu \varepsilon \dot{\omega} \omega$ inappropriate. ${ }^{88}$ The omission of Moses as the subject of the giving of the land in LXX-Josh 1:14 is another example. Here the Greek translator adjusted the text of Joshua to the idea found in the Pentateuch that the land was a gift of Yahweh only. The same concern for harmonization with the Pentateuch accounts for the omission of the phrases in Josh 1:7 ("all the torah that Moses has commanded to you") and 4:10 ("all that Moses had commanded to Joshua"), since all instructions to Joshua derive directly from the Deity, according to the Pentateuch. ${ }^{89}$

Even more remarkable is the Greek translator's knowledge of military affairs and administration. In her study of the vocabulary of the Greek Joshua, Jacqueline Moatti-Fine notes what she calls "une plus grande initiative dans les domaines militaire et géographique." Examples are the numerous renderings of a single Hebrew word, such as נכה "to strike" or לחם "to fight," the distinction between various military groups, ${ }^{90}$ and the use of technical Greek military terms not attested in the Greek Pentateuch or elsewhere in the Greek Bible. ${ }^{91}$ A number of significant variant readings in LXX vis-à-vis MT can be explained as the result of the Greek translator's keen interest in military affairs. In Joshua's appeal to the Transjordanian tribes to aid the remaining tribes with the conquest of Cis-

politeuma of Heracleopolis, recently published by James M. S. Cowey and Klaus Maresch, eds., Urkunden des Politeuma der Juden von Herakleopolis (144/3-133/2 v.Chr.) (P.Polit.Iud.): Papyri aus den Sammlungen von Heidelberg, Köln, München und Wien (Papyrologica coloniensia 29; Wiesbaden: Westdeutscher 2001). For the epigraphical evidence, see William Horbury and David Noy, eds., Jewish Inscriptions of Graeco-Roman Egypt with an Index of the Jewish Inscriptions of Egypt and Cyrenaica (Cambridge: Cambridge University Press, 1992). See further Joseph Mélèze Modrzejewski, Les Juifs d'Egypte, de Ramsès II à Hadrien (Paris: Éditions Armand Colin, 1992); trans. as The Jews of Egypt: From Rameses II to Emperor Hadrian (trans. R. Cornman; Princeton: Princeton University Press, 1995).

88. See Hollenberg, Der Charakter, 5-6.

89. Van der Meer, Formation and Reformulation, 182-85, 210-22; and Michaël N. van der Meer, "Textual and Literary Criticism in Joshua 1:7 (MT and LXX)," in X Congress of the International Organization for Septuagint and Cognate Studies: Oslo, 1998 (ed. B. A. Taylor; SBLSCS 51; Atlanta: Scholars Press, 2001), 355-71.

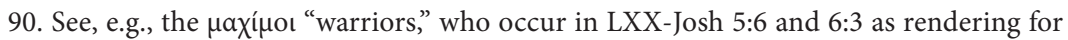
Hebrew אנשי המלחמה, and in Josh 6:7, 9, 13 as equivalent for the Hebrew substantival passive participle Qal החלוץ "men equipped for war." In the Greek Old Testament, the noun occurs only in LXX-4 Reg 19:25 and LXX-Prov 21:19.

91. Moatti-Fine, Josué, 53-66.

\footnotetext{
This essay was published in XII Congress of the International Organization for Septuagint and Cognate Studies, edited by Melvin K. H. Peters, copyright @ 2006 by the Society of Biblical Literature. To purchase copies of this book, please contact SBL Customer Service by phone at 877-725-3334 [toll-free in North America] or 802-864-6185, by fax at 802-864-7626, or by visiting the online SBL Store at www.sbl-site.org.
} 
jordanian Palestine, Josh 1:14, Hebrew עזר becomes $\sigma u \mu \mu a x \varepsilon ́ \omega$, a contextually appropriate rendering, but significant, since it occurs in the Greek Old Testament almost exclusively in the genuine Greek composition 2 Maccabees. ${ }^{92}$

From a syntactical point of view, chapter 10 of the book may be classed as dull, unidiomatic Greek, because of the high percentage of paratactic clause connections with kaí. Yet it abounds with unusual Greek renderings of common

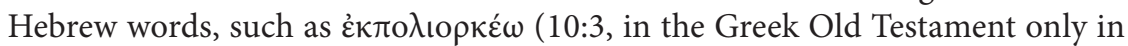

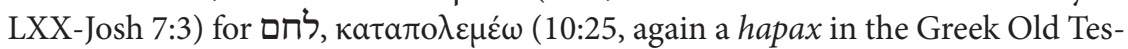

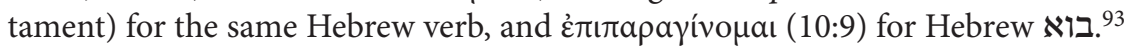
When in the same chapter king Adonibezek hears of the Gibeonites' ruse, the Hebrew text employs the verb שלם "to make peace with," the Greek translator

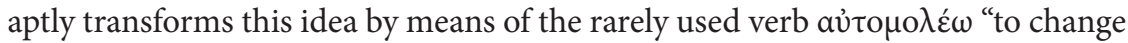
sides, to desert." Samuel Holmes thought the choice of this Greek verb was a guess meant to conceal the Greek translator's lack of knowledge of the precise meaning of the corresponding Hebrew verb. ${ }^{94}$ In the light of the preceding observation, the reverse seems to be more likely. ${ }^{95}$

Interest in military affairs is also clearly discernible in the Greek translator's rewriting of the fall of Jericho, Josh 6 , where the repetitive priestly sections at the beginning of the chapter $(6: 3-4,7-9)$ have been condensed, the discursive sections have been rationalized, and the temporal frame of the narrative somewhat adjusted (6:12) ${ }^{96}$ Rarely used Greek forms, such as the third-person imperatives

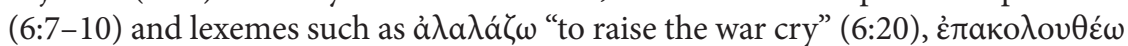
"to follow" (6:8), and oủ $\rho \gamma \varepsilon \dot{\varepsilon} \omega$ "to lead the rear" (6:9), ${ }^{97}$ make it clear that the

92. See the discussion in van der Meer, Formation and Reformulation, 244-45.

93. The Greek verb $\pi \varepsilon \rho \iota \kappa a \theta i \zeta \omega$ "to besiege," which occurs only eighteen times in the Greek Old Testament, out of which five are in the Greek Joshua $(10: 5,31,34,36,38)$. The other places are: LXX-Deut 20:12, 19; LXX-Judg 9:50; LXX-3 Reg 15:27; 16:17; 21(20):1, 1; LXX-4 Reg 6:24; LXX-1 Chr 20:1; 1 Macc 6:19, 20; and 2 Macc 10:33.

94. See, e.g., Holmes, Joshua, 49; Harry M. Orlinksy, "The Hebrew Vorlage of the Septuagint of the Book of Joshua," in Congress Volume: Rome, 1968 (VTSup 17; Leiden: Brill, 1967), 187-95; Emanuel Tov, "The Growth of the Book of Joshua in the Light of the Evidence of the LXX Translation,” in Studies in Bible 1986 (ed. S. Japhet; ScrHier 31; Jerusalem: Magnes, 1986), 321-39.

95. The Greek translator of Deuteronomy also chose an apt, though different, equivalent in 20:12: v́лакоúw; see John W. Wevers, Notes on the Greek Text of Deuteronomy (SBLSCS 39; Atlanta: Scholars Press, 1995), 325.

96. See Klaus Bieberstein, Josua-Jordan-Jericho: Archäologie, Geschichte und Theologie der Landnahmeerzählungen Josua 1-6 (OBO 143; Fribourg: Universitätsverlag; Göttingen: Vandenhoeck \& Ruprecht, 1995), 230-67, with references to older literature.

97. The verb oujpayé $\omega$ "to lead the rear, to be the rear guard" occurs in the Greek Old Testament only here and in LXX-Sir 35:11. The corresponding noun oủpayía occurs also in LXX-Josh 10:19 and LXX-Deut 25:18, as equivalent for the Hebrew verb זנב "to smite in the rear." See Moatti-Fine, Josué, 124: "hapax dans la LXX, ce terme du vocabulaire militaire, bien

This essay was published in XII Congress of the International Organization for Septuagint and Cognate Studies, edited by Melvin K. H. Peters, copyright $\odot 2006$ by the Society of Biblical Literature. To purchase copies of this book, please contact SBL Customer Service by phone at 877-725-3334 [toll-free in North America] or 802-864-6185, by fax at 802-864-7626, or by visiting the online SBL Store at www.sbl-site.org. 
option of a recensionally different Hebrew Vorlage underlying the Greek text should be ruled out. ${ }^{98}$ The Hebrew version with its stress on the priestly and liturgical aspects has been transformed into a narrative with a more military character.

As I have tried to demonstrate in my book, the same concern for logic in narratives dealing with military affairs brought the Greek translator to a drastic shortening of Josh 8:1-29. ${ }^{99}$ The transposition of the famous passage dealing with Joshua's offerings and torah reading on Mount Ebal, Josh 8:30-35 (MT), after Josh 9:1-2 (LXX), must be seen in the same light: only after the threat of the hostile forces had been postponed, owing to their redeployment of troops (Josh 9:1-2), could Joshua and Israel perform the prescribed religious duties in unconquered land. ${ }^{100}$

Significant also are the lexical innovations with respect to the theme of land division. A parcel of land given to the individual groups is variously called

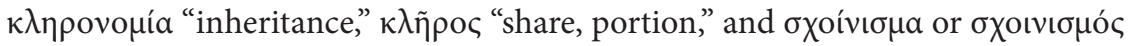
"a piece of land measured out by a $\sigma \chi 0 เ v i ́ o v$, measuring cord," which are technical terms that occur frequently in the Ptolemaic papyri for pieces of land given to soldiers after their military duty that remain family property. ${ }^{101}$ Interesting also are the verbs used by the Greek translator to describe the work of the committee in Josh 18:1-10 charged with measuring out the land. Compared to the Hebrew text, which has the colorless verbs כתב and הלך, the Greek translation again employs

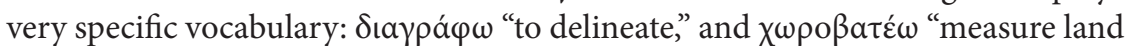
by steps." Whereas the former word is well attested in the Greek Ptolemaic papyri (and hardly so in the Greek Old Testament), the latter verb establishes another exclusive link with the Zenon papyri (P.Cair.Zen. 59329). ${ }^{102}$ In a document dated to 19 April 248 B.C.E., Apollonius and Menippos, two vine dressers, report their

attesté chez Polybe, souligne l'aspect guerrier de cette procession." In the documentary papyri the root oủpay- occurs only in BGU 8, 1784, 5 (first century B.C.E.); P.Dion (Pap.Lugd.Bat. 22) 16, line 15 (109 в.C.E.); and P.Strassburg 8, 742, 6 (second century B.C.E.).

98. So also, with different argumentation, Lea Mazor, "A Nomistic Reworking of the Jericho Conquest Narrative Reflected in LXX to Joshua 6:1-20," Textus 18 (1995): 47-62.

99. Van der Meer, Formation and Reformulation, 465-76.

100. Ibid., 519.

101. Moatti-Fine, Josué, 59-60; Hans-Albert Rupprecht, Kleine Einführung in die Papyruskunde (Darmstadt: Wissenschaftliche Buchgesellschaft, 1994), 82-83.

102. The verb $\chi \omega \rho \circ \beta a \tau \varepsilon \dot{\varepsilon} \omega$ and its derivative $\chi \omega \rho \circ \beta a ́ \tau \eta \varsigma$ occur in the entire corpus of extant classical Greek literature, apart from LXX-Josh 18:8, 9, 9, only in P.Cair.Zen. 59329; in Hero Mechanicus, Dioptra 12; Vitruvius, 8.5.1; and a first-century C.E. epitaph in Corycus from Asia Minor; see Josef Keil and Adolf Wilhelm, eds., Denkmäler aus dem rauhen Kilikien (vol. 3 of Monumenta asiae minoris antiqua; Manchester: Manchester University Press, 1931), no. 694. The usual word for land measuring was $\chi \omega \rho о \gamma \rho \alpha \varphi \varepsilon ́ \omega$, which is also the reading of the recentiores in Josh 18:8; see Moatti-Fine, Josué, 67.

This essay was published in XII Congress of the International Organization for Septuagint and Cognate Studies, edited by Melvin K. H. Peters, copyright ( $\odot 2006$ by the Society of Biblical Literature. To purchase copies of this book, please contact SBL Customer Service by phone at 877-725-3334 [toll-free in North America] or 802-864-6185, by fax at 802-864-7626, or by visiting the online SBL Store at www.sbl-site.org. 
work on the field that they surveyed ( $\dot{\chi} \chi \rho \rho \beta \alpha \tau \eta \dot{\sigma} \sigma \alpha \mu \varepsilon v)$ up to the village Bakchias.

The Greek translator probably also had training or experience in administrative affairs. Whereas the Greek translators of the Pentateuch, Judges, and

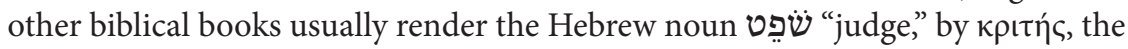

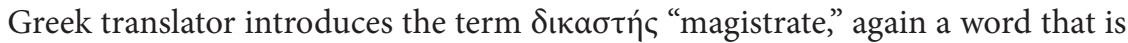
better known from the papyri than the Greek Old Testament. ${ }^{103}$ The use of the noun $\mu \eta \tau \rho$ ó $\pi$ $\lambda_{\iota} \varsigma$ also reflects the Greek translator's knowledge of administrative affairs.

We thus find various literary initiatives employed by the Greek translator of Joshua with respect to the themes of the conquest, division, and administration of land. By contrast, the Greek translation shows less interest in religious affairs. The final chapters have been rendered in a rather straightforward manner without the literary innovations so abundantly present in the first half of the book. ${ }^{104}$ The transformation of the Jericho narrative from a cultic to a military activity is another example. A comparable shift in stress on cultic purity toward historical and military plausibility can be observed in LXX-Josh 5:2-9. ${ }^{105}$

The Greek translator does modify some of the anthropomorphic statements with regard to the Deity ${ }^{106}$ and takes over from the Greek translators of the Pentateuch the distinction between legitimate and illegitimate cultic places $(\beta \omega \mu \mu \varsigma$ and

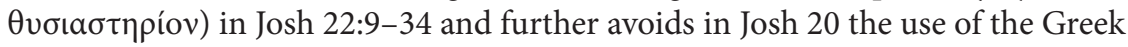

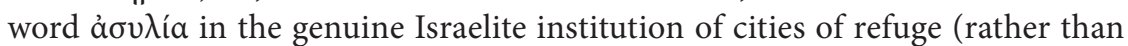
the pagan temple areas), as do the Greek translators of Exodus (21:14), Numbers (35), and Deuteronomy (19:1-13), ${ }^{107}$ but significant renderings are absent in Josh $22-24$.

Returning to the question of competency, we may conclude this section with the observation that the Greek translator must have been a well-educated Jew. His education must have encompassed both classical Hebrew and its ancient lit-

103. LXX-Exod 2:14; LXX-Josh 9:2d (= MT 8:33); 23:2; 24:1; LXX-1 Reg 8:1, 2; 24:16; 1 Esd 8:23; Wis 6:1; LXX-Sir 38:33; Bar 2:1; 3 Macc 6:9; and Aquila’s version of Ps 67(68):6; see Moatti-Fine, Josué, 42-44; Ceslas Spicq, Notes de lexicographie néo-testamentaire: Supplément (OBO 22.3; Fribourg: Universitätsverlag; Göttingen: Vandenhoeck \& Ruprecht, 1982), 149-51: "Dikastès peut désigner le magistrat qui siège au tribunal pour rendre la justice, mais aussi "les juges élus' (Philon, Deus immut. 112, Agr.116)... Il y a surtout ces personnages éminents qui jouent un rôle de premier plan dans l'administration de la cité, et font partie d'un bureau ou des commissions de l'assemblé pour préparer une fête au gérer des fonds."

104. In her study of the religious vocabulary in the Greek Joshua, Moatti-Fine (Josué, 4652) makes clear that the Greek translator of Joshua closely followed the Greek translators of the Pentateuch.

105. Van der Meer, Formation and Reformulation, 335-413.

106. Hollenberg, Der Charakter, 9; Moatti-Fine, Josué, 49-50.

107. See the notes in the La Bible d'Alexandrie series.

This essay was published in XII Congress of the International Organization for Septuagint and Cognate Studies, edited by Melvin K. H. Peters, copyright (C 2006 by the Society of Biblical Literature. To purchase copies of this book, please contact SBL Customer Service by phone at 877-725-3334 [toll-free in North America] or 802-864-6185, by fax at 802-864-7626, or by visiting the online SBL Store at www.sbl-site.org. 
erature, particularly the Pentateuch, and Greek language and culture, including military affairs, which belonged to the regular curriculum of the Greek gymnasium, ${ }^{108}$ as well as juridical and administrative matters. Furthermore, the Greek translator must have had a reasonable knowledge of Palestinian topography.

\section{Authorship of the Greek Translation of Joshua}

If we adopt the observations made above about the relatively early date of the Greek translation, known already to Aristobulus around 175 B.C.E., and exhibiting some remarkable agreements with words found in the Zenon papyri (variable spelling of place names, the spelling of Yabneh as 'Is $\mu v a$ a, the use of the word $\chi \omega \rho \circ \beta a \tau \varepsilon \dot{\varepsilon} \omega)$, we may assume that the translator lived sometime between when the Greek translation of the Pentateuch was made (280 B.C.E.?) and the time when Aristobulus wrote his statement about the influence of the Jewish literature upon Greek philosophy (176-170 в.C.E.) or before the time the Seleucids took over control over Palestine from the Ptolemies (200-198 B.C.E.). Although our information on Jews in the third century B.C.E. is very scanty, it is noteworthy that the information we do have makes clear that only a relatively small group of Jews could have fit the profile sketched out above. Our papyrological and epigraphical data do not provide clear evidence for Jews well versed in both Greek and classical Hebrew. Furthermore, a large number of Jews both in Palestine and Egypt simply lacked the means and the education to perform the time-consuming and expensive task of translating an entire book. ${ }^{109}$ Possibly the Greek translator belonged to the group of the relatively well-to-do former Jewish soldiers who after their military service received landholdings $(\kappa \lambda \tilde{n} \rho \mathrm{ol}$, a term frequently used by the Greek translator of Joshua). The Zenon papyri contain several references to Jewish $\kappa \lambda \eta \rho o \tilde{\chi} \chi \circ$ in the Faiyum. ${ }^{110}$ Since the Zenon papyri also mention a gymnasium in the Faiyum, ${ }^{111}$ it is not impossible that the Greek translator belonged to this milieu and had received his education in the Egyptian Faiyum.

It is also interesting to observe that the documentary papyri from the third century B.C.E. mention a duo of a Jewish father and his son who fit the profile of the Greek translator of Joshua to some extent: they are Drimylos and his

108. Hengel, Judentum und Hellenismus, 120-52.

109. Naphtali Lewis, Papyrus in Classical Antiquity (Oxford: Clarendon, 1974), 129-34, has estimated that the price for an average papyrus roll equaled the two-days' wage of an Egyptian laborer. The Jews mentioned in section 2, "Jews of the Fayûm in the Zenon Papyri," in CPJ 1 lacked the money and education to produce the Greek Joshua. CPJ 1 12, 18, 19, 21, 22 were probably written by professional scribes on behalf of the Jews mentioned in these documents. CPJ 113 (= P.Cair.Zen. 59377) may have been written by the Jews Alexander and Ismaelos, but the Greek of the letter is confused.

110. CPJ 1 18-32.

111. PSI 4, 340; 418, 7; see Hengel, Judentum und Hellenismus, 122.

This essay was published in XII Congress of the International Organization for Septuagint and Cognate Studies, edited by Melvin K. H. Peters, copyright ( $\odot 2006$ by the Society of Biblical Literature. To purchase copies of this book, please contact SBL Customer Service by phone at 877-725-3334 [toll-free in North America] or 802-864-6185, by fax at 802-864-7626, or by visiting the online SBL Store at www.sbl-site.org. 
son Dositheos, known from 3 Macc 1:3 and a number of Greek documentary papyri. ${ }^{112}$ Dositheos held a high position at the Ptolemaic court during the reigns of Ptolemy III Euergetes I (246-222 B.C.E.) and Ptolemy IV Philopator (222-205 B.C.E.). Since the name $\Delta \omega \sigma i \theta \varepsilon$ c , was almost exclusively used by Jews, his Jewish origin is without dispute. ${ }^{113}$ The name of his father, $\Delta \rho \mu \nu$ v́loc "sharp one" has no Jewish background but is so rare in Greek sources, ${ }^{114}$ it it is very plausible to assume that all occurrences in the Greek papyri of the third century B.C.E. refer to the same person.

The career of Dositheos is well known. In a document from the Zenon archive dating from March 240 B.C.E., Dositheos appears in the function of

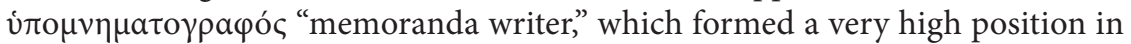
the royal administration. ${ }^{115}$ Other papyri confirm this high position. ${ }^{116}$ In 225 or 224 в.C.E. Dositheos apparently accompanied the king on a tour through the Faiyum. ${ }^{117}$ A few years later, in 222 B.C.E., Dositheos held one of the most prestigious functions in the Ptolemaic empire, that of eponymous priest, and as such he appears in the dating formulae of a few documents. ${ }^{118}$ During the fourth Syrian war (219-217 в.C.E.) he saved the life of Ptolemy IV Philopator, as recorded both by the author of 3 Maccabees (1:3) and Polybius (5.81).

What has not been noted so far is the fact that the rare name of Dositheos's father, $\Delta \rho \mu v^{\prime} \lambda o c$, occurs a few times in the so-called "Syrian dossier" of the Zenon papyri, that is, the documents dealing with Zenon's journeys through Pal-

112. On Dositheos, see Alexander Fuks, "Dositheos son of Drimylos: A Prosopographical Note," Journal of Juristic Papyrology 7-8 (1953-1954): 205-9; CPJ 1127 (pp. 230-36); Mélèze Modrzejewski, The Jews of Egypt, 56-61.

113. CPJ 1, p. 231.

114. Apart from the papyri here mentioned, the name Drimylos occurs only in the seventh mime of Herodas (ca. 270-260 B.C.E.) as a sleeping slave to be hit by another servant (Pistus); as an extremely rich uncle of a certain Simon, in Lucian, The Dream, or the Cock 14.16 (second century C.E.); and as the name of a mountain in Pseudo-Plutarchus, De fluviis 20.4.1. Two other persons with the name Drimylos but from later times are recorded by Peter M. Fraser and Elaine Matthews, The Aegean Islands, Cyprus, Cyrenaica (vol. 1 of A Lexicon of Greek Personal Names;

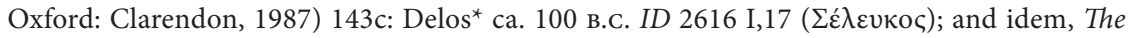
Peleponnese, Western Greece, Sicily and Magna Graeca (vol. 3a of A Lexicon of Greek Personal Names; Oxford: Clarendon, 1987), 135a: Messenia. Messene II/I в.C. SEG XI 979,61.

115. P.Mich.Zen. 55 = CPJ 1 127a; Rupprecht, Kleine Einführung, 43, 54, 56.

116. P.Ent. 19 = CPJ 1 127b; see also P.Ryl. IV.576; Hans Hauben, "A Jewish Shipowner in Third-Century Ptolemaic Egypt," Ancient Society 10 (1979): 167-70.

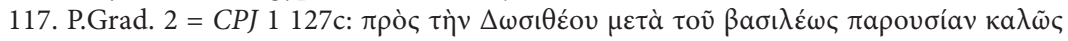

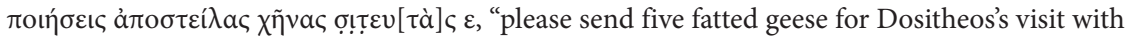
the king."

118. P.Tebt. 815 col.III fr.3 recto = CPJ 1 127d; P.Hib. 90 = CPJ 1 127e; P.dem.Berl. 3096; SB XVIII 14013; see Willy Clarysee and G. van der Veken, The Eponymous Priests of Ptolemaic Egypt (Papyrologica Lugduno-Batava 24; Leiden: Brill, 1983), 14-15: Dositheos was eponymous priest from 7 September 223 B.C.E. until 27 August 222 B.C.E.

This essay was published in XII Congress of the International Organization for Septuagint and Cognate Studies, edited by Melvin K. H. Peters, copyright @ 2006 by the Society of Biblical Literature. To purchase copies of this book, please contact SBL Customer Service by phone at 877-725-3334 [toll-free in North America] or 802-864-6185, by fax at 802-864-7626, or by visiting the online SBL Store at www.sbl-site.org. 
estine (260-258 в.C.Е.), as well as some other documentary papyri dating from the Faiyum in the middle of the third century B.C.E.. According to Leiden Zenon papyrus no. 59, Drimylos was a mule driver ( $\sigma v v \omega \rho ı \tau \eta \dot{\zeta}$ ) who belonged to the personnel of Zenon's tour through Palestine in 259 в.C.E. ${ }^{119}$ In another document

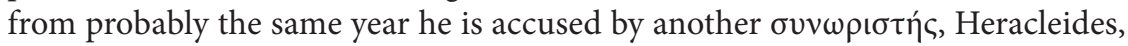
for entertaining lucrative extra duties instead of the job he is paid for. ${ }^{120}$

We find Drimylos in some later documents in the Faiyum as merchant. In P.Cair.Zen. 59691 and 59692 his name appears in a memorandum concerning money and a list of goods. Among these, mention seems to be made of dates of palm trees ( $\sigma \varphi v p i ́ \delta \varepsilon \varsigma \varphi$ olvík $\omega v)$, which reminds one of LXX-Josh 5:12, and sev-

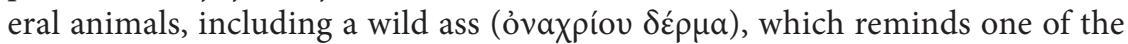
gift of foreign animals sent to Ptolemy II Philadelphus by Toubias via Zenon and Apollonius, among which were various wild mules. ${ }^{121}$ In another papyrus (P.Lille 58, an account from the middle of the third century B.C.E.), Drimylos is explicitly called a $\Sigma$ v́poc, the early Ptolemaic designation for Jews. ${ }^{122}$ Since all references to Drimylos date from roughly the same period (259-222 в.C.E.), place (Faiyum), and persons (Zenon), and given the fact that the name Drimylos is very rare, it is highly probable that we are dealing here with the same person in all the documents. ${ }^{123}$

Father Drimylos and his son Dositheos seem to combine the characteristic competences of the Greek translator of Joshua. Drimylos was apparently a native from Palestine, and as Zenon's attendant in Palestine he must have had good knowledge of the country and its languages. Drimylos may have used the fortune he seems to have earned as merchant to afford a good education for his son,

119. CPJ 13 ; Durand, Des grecs, 263-64.

120. PSI 4, 406; see Reinhold Scholl, Sklaverei in den Zenonpayri: Eine Untersuchung zu den Sklaventermini zum Sklavenerwerb und zur Sklavenflucht (Trierer historische Forschungen 4; Trier: Verlag Trierer Historische Forschungen, 1983), 58-64; Durand, Des grecs, 167-74. Herakleides accuses Drimylos and Dionysios (probably identical with the Dionysios mentioned in

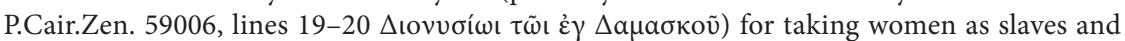
selling them for unusually high prices (150 drachmas) and buying another for 300 drachmas, the highest price paid for a slave, known from the Ptolemaic period (Scholl, Sklaverei, 63). Only a year earlier (260 B.C.E.) Ptolemy II Philadelphus had tried to restrict slavery in Palestine, but this royal prostagma was really more concerned with securing the produce of taxes and therefore only restricted to the free men and explicitly excludes native women from Syria and Phoenicia; see C.Ord.Ptol. 21-22, translated by Roger S. Bagnall and Peter Derow, The Hellenistic Period: Historical Sources in Translation (Blackwell Sourcebooks in Ancient History; Oxford: Blackwell, 2004), no. 64 (pp. 111-13); Hölbl, Geschichte des Ptolemäerreiches, 63.

121. P.Edg. $13=$ SB $6719=$ P.Cair.Zen. $59075=$ CPJ 15.

122. CPJ 1, pp. 4-5.

123. It may therefore not come as a surprise that Zenon and his friend Philon had put their hope on Drimylos's son when they wanted to accelerate the demise of their friend Hermokrates

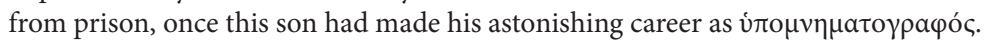

This essay was published in XII Congress of the International Organization for Septuagint and Cognate Studies, edited by Melvin K. H. Peters, copyright @ 2006 by the Society of Biblical Literature. To purchase copies of this book, please contact SBL Customer Service by phone at 877-725-3334 [toll-free in North America] or 802-864-6185, by fax at 802-864-7626, or by visiting the online SBL Store at www.sbl-site.org. 
which allowed the latter to climb his way up to the top as royal secretary. ${ }^{124}$ In this function Dositheos must have written many documents and thus have been able to write good Greek and must have had a very good knowledge of administrative affairs. As direct assistant of the third and fourth Ptolemaic kings, he joined the kings on their military campaigns, also on their campaigns through Palestine, as is evident from 3 Macc 1:3.125

It need not be stressed here that the identification of Dositheos and Drimylos as the authors of the Greek Joshua rests on speculation. The present documents do not allow for a firm identification of Dositheos and Drimylos as the authors of LXX-Joshua, or any other Jew from that period with similar training and competences. Until new papyrological discoveries throw more light on the origin of the Greek Joshua and the persons mentioned here, the thesis must remain an unverifiable hypothesis.

\section{Purpose of the Greek Translation of Joshua}

In the meantime, this kind of historical guessing may be of use in determining the purposes of the Greek Joshua. Study of the vocabulary of the Greek Joshua made it clear that the Greek translator's interests were in the field of history, administration and warfare rather than religion. This corresponds well with recent theories concerning the origin and purpose of the Greek Pentateuch. As Sylvie Honigman puts it, the need for a Greek translation of the Pentateuch was probably more a matter of cultural prestige than piety. ${ }^{126}$ The Greek translation of a book dealing

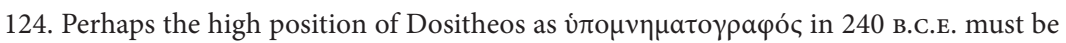
seen against the background of the first revolt of the native Egyptians against the foreign Macedonian occupation in 245 B.C.E., which forced Ptolemy III Euergetes I to break off his successful military campaign deep in the rival Seleucid empire; see Hölbl, Geschichte des Ptolemäerreiches, 48-49. With the Macedonians under arms along the border, the Jewish population must have been an interesting group for the Ptolemaic rulers, because of their relatively independent status. The rapid career of Tobias's son Joseph as chief tax-collector in Palestine under the same Ptolemaic king, Eurgetes I, according to Josephus, Ant. 12.160-222, is another another example of the growing influence of Jews in Egypt during the second half of the third century B.C.E.

125. The author of 3 Maccabees calls Dositheos an apostate, someone who at a later period

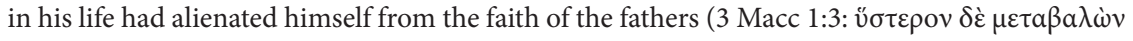

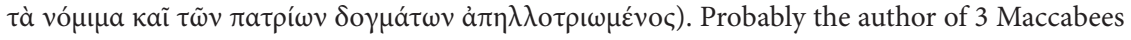
referred to Dositheos's service as eponymous priest of the deified Macedonian rulers of Egypt. From the Macedonian point of view this job was only a honorary post that did not require conversion but from an orthodox Jewish point of view of orthodox must have meant apostasy; see Mélèze Modrzejewski, Jews of Egypt, 60.

126. Sylvie Honigman, The Septuagint and Homeric Scholarship in Alexandria: A Study in the Narrative of the Letter of Aristeas (London: Routledge, 2003). The option of a liturgical setting for the Greek translation of Joshua, as argued by Henry St. J. Thackeray, The Septuagint and Jewish Worship: A Study in Origins (London: Oxford University Press, 1923), is now completely

This essay was published in XII Congress of the International Organization for Septuagint and Cognate Studies, edited by Melvin K. H. Peters, copyright @ 2006 by the Society of Biblical Literature. To purchase copies of this book, please contact SBL Customer Service by phone at 877-725-3334 [toll-free in North America] or 802-864-6185, by fax at 802-864-7626, or by visiting the online SBL Store at www.sbl-site.org. 
with such an important period in the history of the Jewish people, namely, the conquest and division of Palestine, may have served the same purpose.

In a multicultural empire in its formative stages, promoting one's own cultural heritage was very important. Already in the first decades of the third century B.C.E. Manetho offered a Greek version of the Egyptian history (Aigyptiaka, ca. 280 B.C.E.), while Berossus of Babylon did the same for the Babylonian history (Babyloniaka, ca. 290 в.C.E.). Jewish Hellenistic writings of the same period (third and second century B.C.E.) are very much concerned with presenting their history, which in their view emulated that of the Greeks (cf. Demetrius, Artapanus, Aristobulus, and Eupolemos). Historical writings from Jewish Greek authors from a somewhat later period, such as Nicolas of Damascus and Flavius Josephus, also reflect the same cultural polemics. ${ }^{127}$ The latter two examples also make it clear that serving under a ruler with a problematic relationship with the Jewish people, such as Herod (Nicolas) and Vespasian and Titus (Josephus), did not restrain but rather encouraged the Jewish historiographers to glorify the past of the Jewish people.

If the royal degree by Ptolemy IV Philopator from 215/214 B.C.E. dealing with the registration of Dionysiac priests indeed reflects anti-Jewish measures and forms the historical background for the narrative in 3 Maccabees, as argued by Mélèze Modrzejewski, ${ }^{128}$ the period of the last decades of the third century B.C.E. provides a plausible background for early Jewish apologetic historiography

abandoned. The book of Joshua in all likelihood has never played a significant role in Jewish (or Christian) liturgy. A cultural setting was already argued by Bruno H. Stricker, De brief van Aristeas: De Hellenistische codificaties der preahelleense godsdiensten (Verhandelingen der Koninklijke Nederlandse Academie van Wetenschappen, afd. Letterkunde, Nieuwe reeks, 62.4; Amsterdam: Noord-Hollandsche Uitgevers Maatschappij, 1956); see further Bickerman, "The Septuagint as a Translation"; Dominique Barthélemy, "Pourquoi la Torah a-t-elle été traduite en grec?" in On Language, Culture and Religion: In Honor of E. A. Nida (The Hague: Mouton, 1974), 23-41, repr. in Etudes d'histoire du texte de l'Ancien Testament (OBO 21; Fribourg: Universitätsverlag; Göttingen: Vandenhoeck \& Ruprecht, 1978), 322-40; Harl, Dorival, and Munnich, La bible grecque des Septante, 38-82; Mélèze Modrzejewski, Jews of Egypt, 99-119. In a reaction to the work of Stricker, Sebastian P. Brock ("The Phenomenon of the Septuagint," in The Witness of Tradition: Papers Read at the Joint British-Dutch Old Testament Conference Held at Woudschoten, 1970 [OtSt 17; Leiden: Brill, 1972], 23-36) objected that "the Greeks and Romans after them were perfectly content with their own literary heritage" (14), but to my mind this circumstance would only have stimulated their oriental subjects to glorify their own cultural heritage.

127. Hengel, Judentum und Hellenismus, 183-90.

128. BGU IV 1211 = C.Ord.Ptol. 29 = Bagnall and Derow, Hellenistic Period, no. 160. Anti-Jewish sentiments can already been found in the work of Manetho; see their refutation in Josephus's Against Apion. See further the discussion in Mélèze Modrzejewski, Jews of Egypt, 135-57, who thinks of Dositheos as the evil genius behind an early assimilation policy, comparable to the later Hellenizing high priest Menelaos (p. 152). There is no evidence for this assumption. Probably both Menelaos and Dositheos would have seen themselves rather as unconventional defenders of their Jewish race.

This essay was published in XII Congress of the International Organization for Septuagint and Cognate Studies, edited by Melvin K. H. Peters, copyright $@ 2006$ by the Society of Biblical Literature. To purchase copies of this book, please contact SBL Customer Service by phone at 877-725-3334 [toll-free in North America] or 802-864-6185, by fax at $802-864-7626$, or by visiting the online SBL Store at www.sbl-site.org. 
(Demetrius, Artapanus, perhaps Pseudo-Eupolemos). Although the Greek Joshua is not a free composition with the same polemical overtones in fluent Greek, but rather a faithful translation of an ancient book with the same language, it does present part of the Jewish glorious and honorable history that can be understood by Greek readers.

These last decades of the third century B.C.E. were also the years in which a bitter war was fought over Palestine between the Ptolemies and the Seleucids (the fourth in a series of so-called Syrian wars). In the battle of Raphia in 217 B.C.E. Ptolemy IV Philopator still managed to maintain Palestine for the Ptolemaic empire. Only two decades later, however, the area was definitively lost for Egypt. A faithful but intelligent Greek translation of the book dealing with the former conquest of the same area (Palestine) by the Jewish people must have been of interest for the Ptolemaic court as well. ${ }^{129}$ The Greek translation of Joshua was therefore probably meant both to strengthen the cultural position of Jews in the early Ptolemaic Empire and to provide the royal court with a faithful rendering of a book concerning the history of such a disputed part of the empire.

\section{CONCLUSION}

In terms of hard evidence for a third-century B.C.E. Egyptian provenance of the Greek Joshua, we are not very much further than where this short paper started. Nevertheless, I believe the evidence posed by the reference in the work of Aristobulus deserves more attention than has been given hitherto. The similarities in translation technique between the Greek Pentateuch and the Greek Joshua,

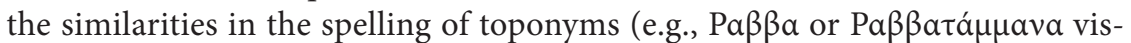
à-vis $\Phi_{\imath} \lambda \alpha \delta \varepsilon \dot{\lambda}(\varphi ı)$ between the Zenon documents and the Greek Joshua, the unspecified use of the word $\pi a \rho a ́ \lambda ı \varsigma$, as well as the Greek translator's invention

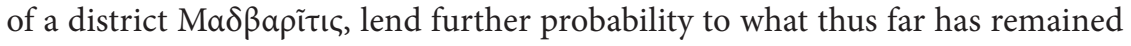
a vague intuition. Of particular interest are the almost exclusive connections between the two corpora with respect to the spelling of Jamnia and the use of the Greek verb $\chi \omega \rho o \beta a \tau \varepsilon ́ \omega$.

A reading of the Greek translation on its own and within the context of contemporary sources makes it possible to draw out the profile of the Greek translator as a Jew well versed both in Greek and classical Hebrew and familiar with both the ancient Jewish literature and the geography of Palestine and the military, administrative, and juridical institutions of contemporary Ptolemaic Egypt. The period in which Ptolemy IV Philopator reigned over Egypt and Palestine (221-205 B.C.E.), in which conquest and control over Palestine was high on the political agenda of the Ptolemaic court and in which cultural propaganda from Jewish side flourished, provides a plausible background for the origin of the

129. Honigman, Septuagint and Homeric Scholarship, 117.

\footnotetext{
This essay was published in XII Congress of the International Organization for Septuagint and Cognate Studies, edited by Melvin K. H. Peters, copyright (C 2006 by the Society of Biblical Literature. To purchase copies of this book, please contact SBL Customer Service by phone at 877-725-3334 [toll-free in North America] or 802-864-6185, by fax at 802-864-7626, or by visiting the online SBL Store at www.sbl-site.org.
} 
Greek Joshua. It remains an interesting but unverifiable hypothesis to think of the Jewish high official Dositheos and his father Drimylos, a former assistant of Zenon on his tour through Palestine, as the possible Greek translators of Joshua.

This essay was published in XII Congress of the International Organization for Septuagint and Cognate Studies, edited by Melvin K. H. Peters, copyright ( 2006 by the Society of Biblical Literature. To purchase copies of this book, please contact SBL Customer Service by phone at 877-725-3334 [toll-free in North America] or 802-864-6185, by fax at 802-864-7626, or by visiting the online SBL Store at www.sbl-site.org. 